\title{
Some Remarks on the Art of Exegesis in the Kalophonic Style
}

\section{MARIA ALEXANDRU *}

${ }^{\star}$ Aristotle University of Thessaloniki, Faculty of Fine Arts. - malexand@mus.auth.gr.

\begin{abstract}
The present article focuses on the technique and art of the so-called exegesis, the traditional

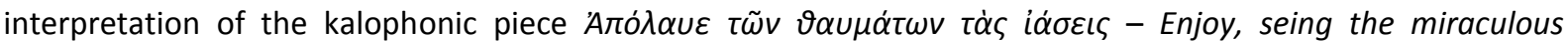
healings, in honor of St Demetrios, by St John Koukouzeles, in the first authentic mode. It is based on the manuscripts Zakynthos 7, Metochion Panagiou Taphou 728, and three Anthologia from the Music School of the Putna Monastery, and highlights several exegetical procedures through microsyntactical and generative analyses of chosen passages of the piece. The profile of the kalophonic melody revealed through the slow exegesis is mainly characterized by stepwise up-and-down movements of the voice around and between the structural notes, with few skips only, and in a perfect balance with the poetical text, which emerges for the singer and the listener syllable by syllable, carried on a continuous melodic flow, a sort of Byzantine 'unendliche Melodie'.
\end{abstract}

Keywords: Byzantine chant, kalophonic style, St John Koukouzeles, Mathematarion, exegesis.

\section{Introduction}

Byzantine kalophonia has been aknowledged to be the peak in the evolution of Psaltic Art so far. A musical expression of hesychasm during the Palaeologan period, it left a strong legacy to the generations of chanters of the post-Byzantine era and comes to be rediscovered with the support of Byzantine musicology since the last decades of the $20^{\text {th }}$ century onwards. ${ }^{1}$

A crucial point in the study of kalophonia is the issue of exegesis, of traditional rendition of this repertoire which displays wide vocal range through all the registers of the human voice, refined melodic formulas in highly skilful combinations, and subtle modulations: a trully good and beautiful art both on the level of composition and the musical interpretation it calls for.

The quality of the composition is expressed firstly in the late Middle Byzantine notation. By approaching the piece in a prelimiray stage through singing the basic metrophonic and rhythmic structure, one cannot but be amazed about the fine equilibrum of the melodic phrases and the harmonic succession of theseis clothing the poetical text with plethora of music rhetorical formulas. The hymnographic text itself is expanded with many repetitions of syllables and words (anagrammatismoi), and lofted into the realm of the ineffable with the insertion of kratemata at different points of the piece.

\footnotetext{
${ }^{1}$ Cf. Egon Wellesz, A History of Byzantine Music and Hymnography, $2^{\text {nd }}$ ed. revised and enlarged (Oxford: Clarendon Press, 1962), p. vi. Edward Vinson Williams, "John Koukouzeles' Reform of Byzantine Chanting for Great Vespers in the Fourteenth Century," PhD Dissertation (Yale University, University Microfilms, Ann Arbor, Michigan, 1969). Kenneth Levy, "Le 'tournant décisif' dans I' histoire de la musique byzantine 1071-1261," in XVe Congrès International d'Études Byzantines, Rapports et Co-Rapports III, Art et Archéologie (Athens, 1976), p.

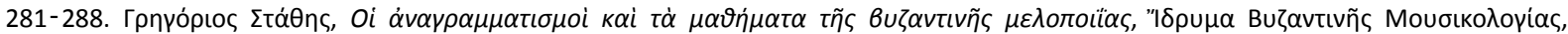

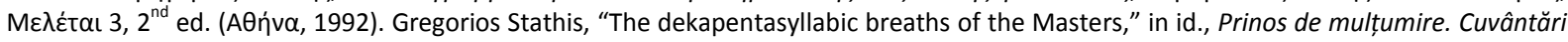

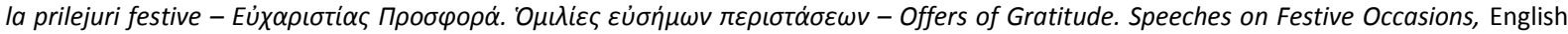
transl. Sorina Chiper, edited by Maria Alexandru, Adrian Sîrbu, and Diana-Beatrice Andron (Iași: Artes, 2018), p. 25-83. Alexander Lingas, "Hesychasm and psalmody," in Mount Athos and Byzantine Monasticism, edited by A. Bryer \& M. Cunningham (London: Variorum, 1996), p. 155-168. Id., "Preliminary reflections on studying the liturgical place of Byzantine and Slavonic melismatic chant," in Palaeobyzantine Notations III, Acta of the Congress held at Hernen Castle, The Netherlands, in March 2001, edited by G. Wolfram, Eastern Christian Studies 4 (2004), p. 147-155.
} 
Tracing then the history of the transmission of kalophonic mathemata, one comes accross the slow exegesis written down by Chourmouzios the Archivist in the first half of the $19^{\text {th }}$ century, which however reflects a much older performance practice of this repertoire.

The aim of this article is to briefly point at some basic techniques which can be observed in the Chourmouzian

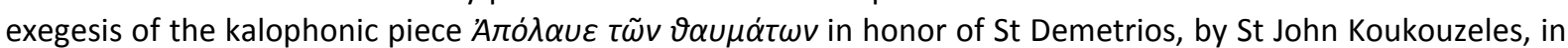
the first authentic mode. ${ }^{2}$ The basic sources of investigation are the Mathematarion Zakynthos 7, an autograph by Gregorios Mpounes Alyates, which can be dated around the middle of the $15^{\text {th }}$ century (1440ies), and Metochion Panagiou Taphou 728, containing Chourmouzios' handwriting with the exegesis of the piece (around 1830). ${ }^{3}$ Along with the Zakynthian Mathematarion, which was the Vorlage for Chourmouzios' slow exegesis, also three Anthologia of the famous Music School of the Putna Monastery have been consulted, belonging the timespan $1400-1545 .^{4}$

After briefly presenting the text of the aforementioned piece, some paradigms will be shown, which point at basic features of the exegetical craft and art, and lead to a sketch of some conclusions concerning the slow exegesis for the kalophonic mathemata and the melodic profile of this repertory.

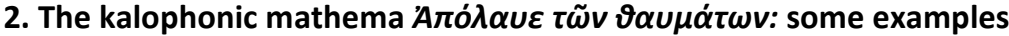

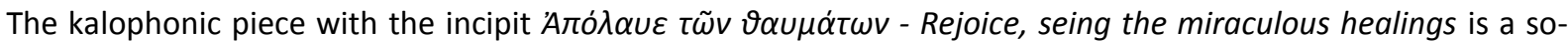

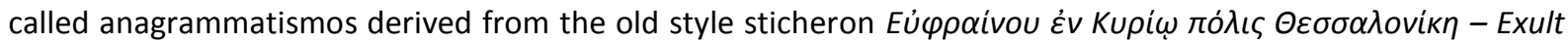
in the Lord, o city of Thessalonica, by Georgios Sikeliotes (SAV 164). ${ }^{5}$

It is one of the seven kalophonic pieces in honor of St Demetrios the Great Martyr and Myroblite, the protector of the aforementioned city, ${ }^{6}$ which in the Zakynthian Mathematarion is connected to the name of St John Koukouzeles (ca. 1270 - † before 1340). ${ }^{7}$

\footnotetext{
${ }^{2}$ This article is part of a research begun in 2020 with the occasion of the $24^{\text {th }}$ edition of the Putna Colloquia and a larger study on the theme is in preparation for a future edition.

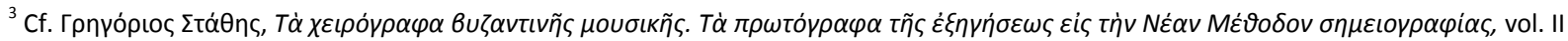

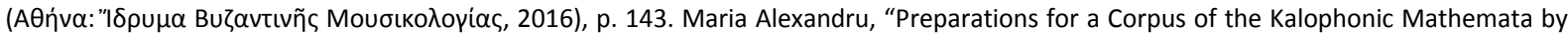
St John Koukouzeles" (forthcoming).

${ }^{4}$ For the Putna Music School, cf. Anne E. Pennington, Muzica în Moldova Medievală. Secolul al XVI-lea, cu un eseu de D. Conomos, ed. bilingvă (engleză-română) T. Moisescu, trad. C. Stihi-Boos (Bucureşti: Editura Muzicală, 1985). Gheorghe Ciobanu and Marin lonescu, eds., Antologhionul lui Evstatie Protopsaltul Putnei, Izvoare ale Muzicii Româneşti V, Documenta (Bucureşti: Editura Muzicală, 1983). For further

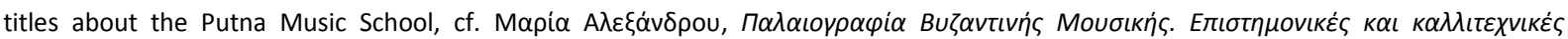

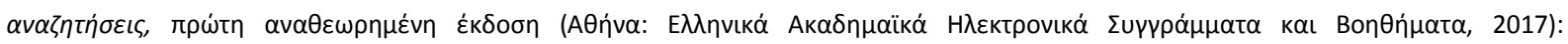
https://repository.kallipos.gr/handle/11419/6487 (opens with mozilla), p. 641, click there on the icon 罯.

${ }^{5}$ Cf. Christian Troelsgård, "A List of Sticheron Call-Numbers of the Standard Abridged Version of the Sticherarion. Part I (The Cycle of the Twelve Months)," Cahiers de l' Institut du Moyen-Âge Grec et Latin 74 (2003), 3-20: 7: https://cimagl.saxo.ku.dk/download/74/74Troelsgaard3-20.pdf (17.9.2020). For the ascription to Georgios Sikeliotes, cf. Lidia Perria and Jørgen Raasted, eds. Sticherarium Ambrosianum, Monumenta Musicae Byzantinae, Facsimiles XI, Pars Principalis (Copenhagen:

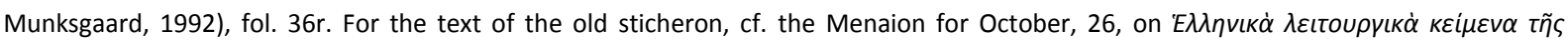

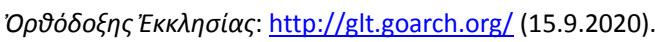

${ }^{6} \mathrm{Cf}$. also plate 23 .

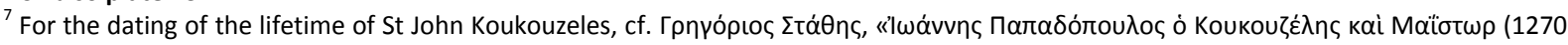

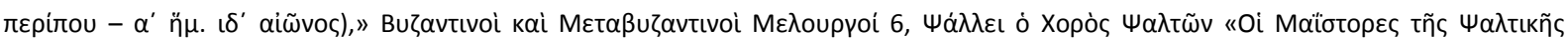

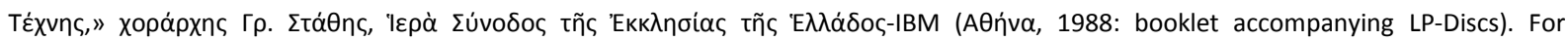

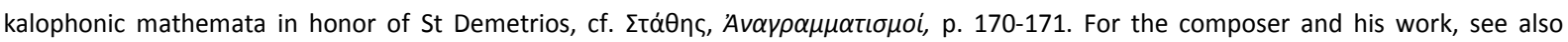

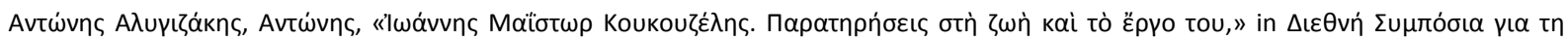

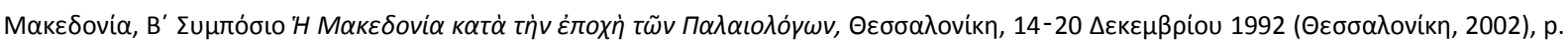

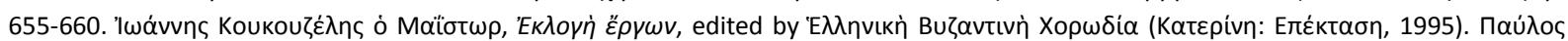

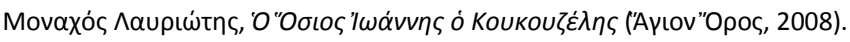


More precisely, the chosen kalophonic piece is introduced in Zak. 7, p. 98, by the following rubric: ${ }^{8}$

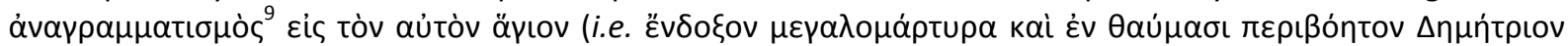

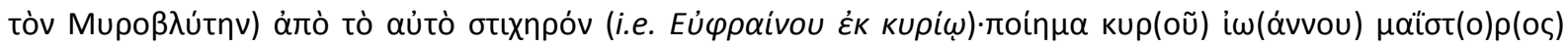

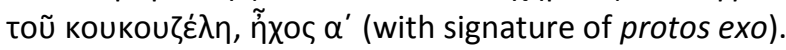

Table 1 shows the text of the piece, along with an English translation. This is followed by plate 1 with the beginning of the piece from the Zakynthos Mathematarion, with the insertion of alphabetic transnotation. Plate 2 displays the first four kola of the piece, along with a transcription on staff, which contains the basic interval and rhythmical structure. What is shown in the latter plate is an approach to trace one of the different aspects covered by the old practice of the so-called metrophonia (measuring of the 'voices' i.e. of the intervals written in the late Middle Byzantine notation, as measured with the unit of the step [that is the tone, which can be of various sizes, according to its position in the reference mode]). ${ }^{10}$

\begin{tabular}{|c|c|c|}
\hline \multicolumn{2}{|c|}{$\begin{array}{l}\text { Anagrammatismos by St John Koukouzelis, } \\
\text { according to Zak. 7, pp. } 98-99\end{array}$} & $\begin{array}{l}\text { Translation of the main verses } \\
\text { (without the anagrammatismoi) }\end{array}$ \\
\hline 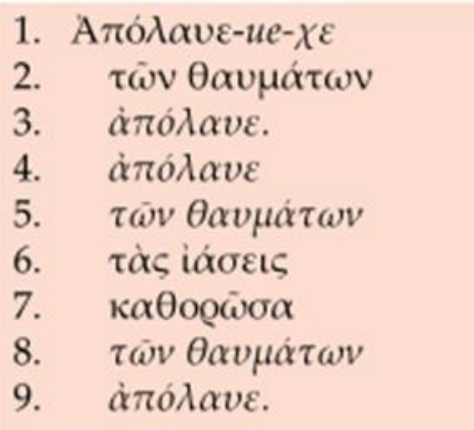 & $\begin{array}{l}\text { first } \\
\text { authentic } \\
\text { from D } \\
\text { (with } \\
\text { traces of } \\
\text { proto- } \\
\text { barys) }\end{array}$ & $\begin{array}{l}\text { Enjoy, seeing the miraculous } \\
\text { healings. }\end{array}$ \\
\hline 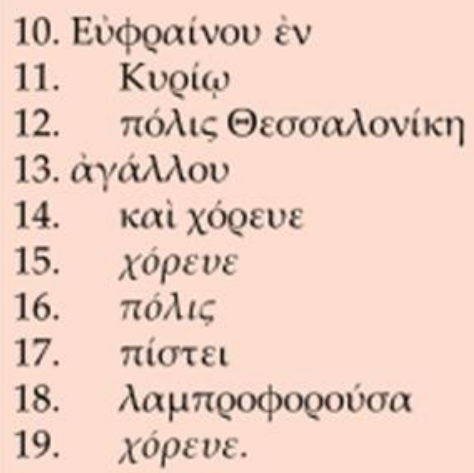 & $\begin{array}{l}\text { plagal of } \\
\text { 1st }\end{array}$ & $\begin{array}{l}\text { Rejoice in the Lord, } \\
\text { city of Thessaloniki, } \\
\text { jubilate } \\
\text { and dance, }\end{array}$ \\
\hline
\end{tabular}

\footnotetext{
${ }^{8}$ The explanations in brackets with the id est are given according to Zak. 7, p. 95. See also the corresponding rubrics in MPT 728, rendered

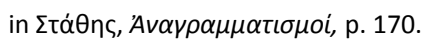

${ }^{9}$ Anagrammatismos is a kalophonic piece based on the text of a troparion from the Old Sticherarion, however with a new order of the verses and many repetitions of words and syllables, highlighting some aspects of the old text, according to the kalophonic composer's

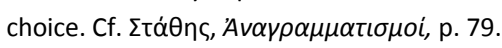

${ }^{10}$ It is mainly based on research conducted by loannis Arvanitis, "A Way to the Transcription of Old Byzantine Chant by means of Written and Oral Tradition," in Byzantine Chant. Tradition and Reform, Acts of a Meeting held at the Danish Institute at Athens, 1993, edited by

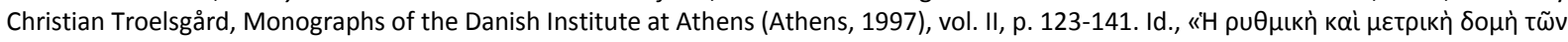

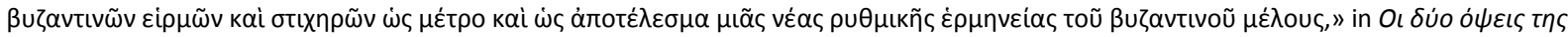

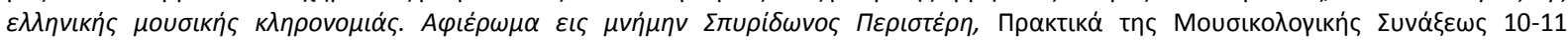

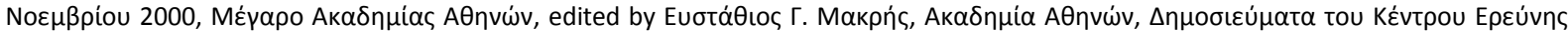

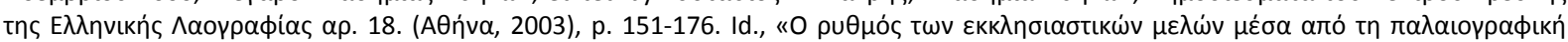

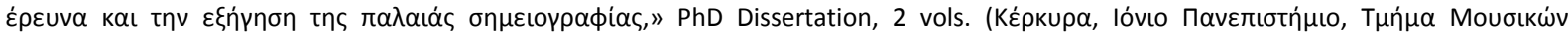
$\Sigma \pi$ ou $\delta \dot{\omega} v, 2010)$. For other research on the theme, cf. the works cited in the footnote 12 . On different aspects of metrophonia, cf. Maria Alexandru, "Observations on the diastematic principles in Byzantine musical notations, with emphasis on Gregorios Mpounes Alyates' method of metrophonia, and some links to analogous phenomena in Western Chant," Artes 13 (2013), p. 129-182.
} 


\begin{tabular}{|c|c|c|}
\hline Anazrammatismos by $5 t$ John Koukouzeli, according to Zak & pp. 98.99 & Translation of the main verves (without the anagrammatismoi) \\
\hline 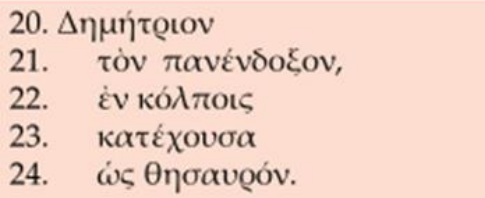 & $\begin{array}{l}\text { first } \\
\text { authentic }\end{array}$ & $\begin{array}{l}\text { having the most glorious Demetrios } \\
\text { in your bossom as a treasure. }\end{array}$ \\
\hline 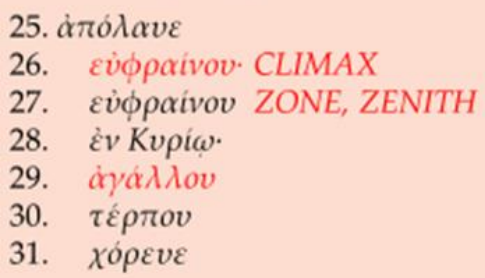 & $\begin{array}{l}\text { 4th auth. } \\
\text { legetos } \\
\text { pl. of 1st }\end{array}$ & $\begin{array}{l}\text { Enjoy, rejoice in the Lord, jubilate, be } \\
\text { delighted, dance }\end{array}$ \\
\hline 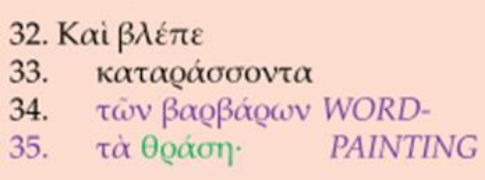 & $\begin{array}{l}\text { nenano- } \\
\text { pl. of } 2 \text { nd }\end{array}$ & $\begin{array}{l}\text { And see him dashing down the } \\
\text { rashness of the barbars. }\end{array}$ \\
\hline 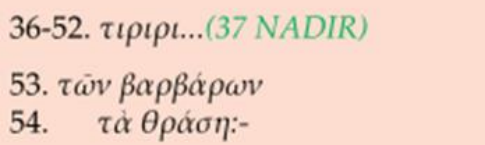 & $\begin{array}{l}\rightarrow 1 \text { st, } \\
\text { barys, } 1 \text { st }\end{array}$ & $\begin{array}{l}\text { Kratema tiriri... } \\
\text { the rashness of the barbars. }\end{array}$ \\
\hline
\end{tabular}

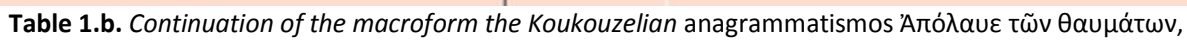
according to the Mathematarion Zakynthos 7, p. 98-99.

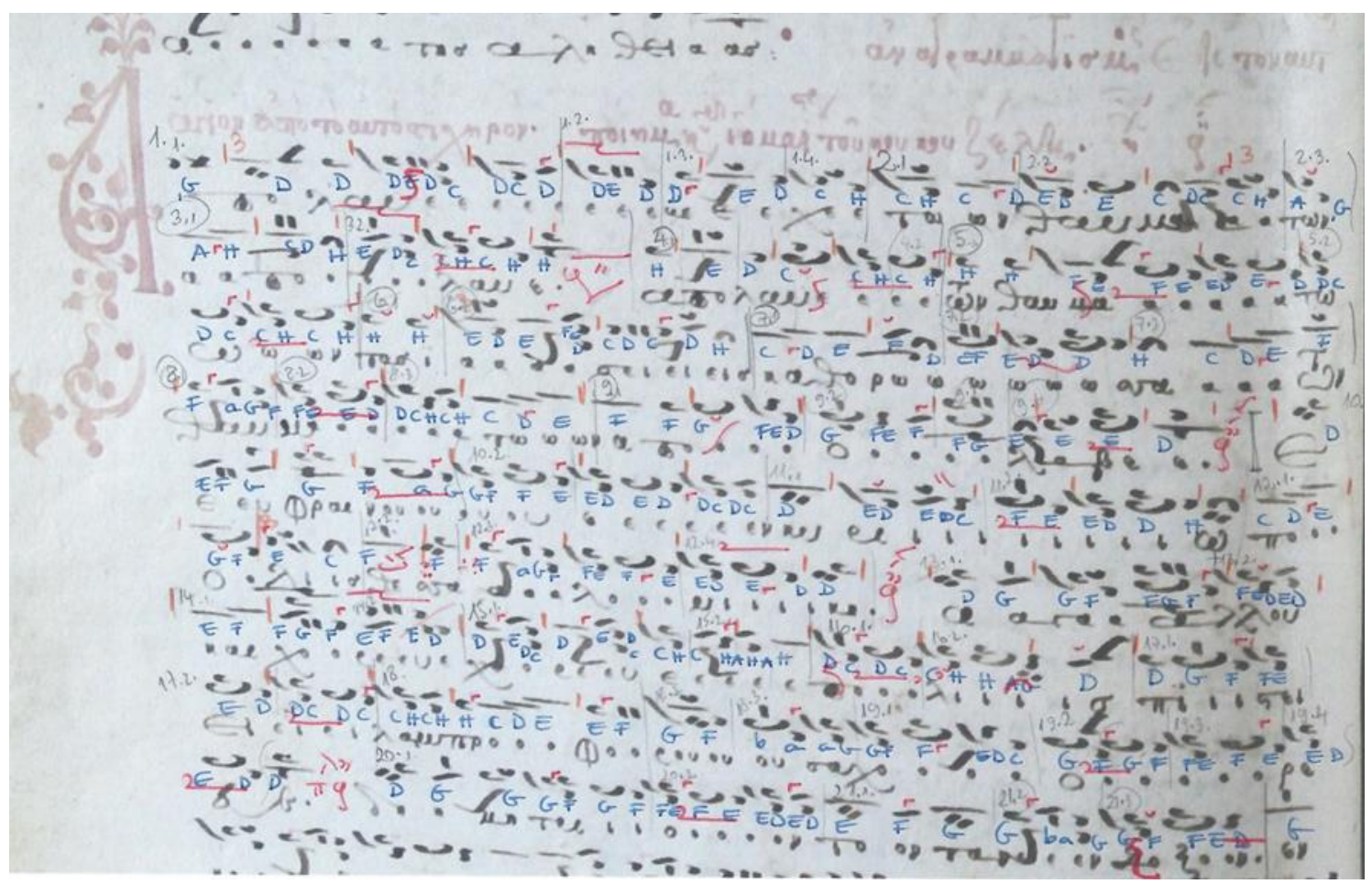

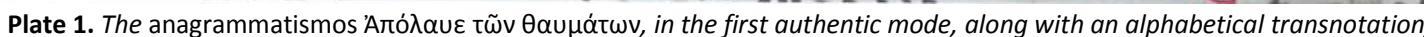
in blue ink. It starts on D and not on a, as one would do in a first approach (because of the exo signature). ${ }^{11}$

\footnotetext{
${ }^{11}$ This choice is based on the contextualized study of the anagrammatismos, which includes also some manuscripts of the Putna-School and the slow exegesis by Chourmouzios, which starts on Pa-D. There is also a precious transnotation into staff notation of this piece by Marin Ionescu, published in Gheorghe Ciobanu, Marin lonescu, and Titus Moisescu, Școala Muzicală de la Putna. Ms. Nr. 56/544/576 I-P.II - Stihirar, Transcrieri în notație liniară, Izvoare ale Muzicii Românești III B, Transcripta (București: Editura Muzicală, 1984), transcription nr. 12, p. 57-61. The transcriber notes that in a manuscript he consulted (Studion 154, A.D. 1430), the signature contained both the first authentic and the third plagal mode (ibid., p. 61, note 1).See also plate 3. This phenomenon needs further comparative investigation on a larger scale, with sources on Middle Byzantine notation and their exegeses.
} 


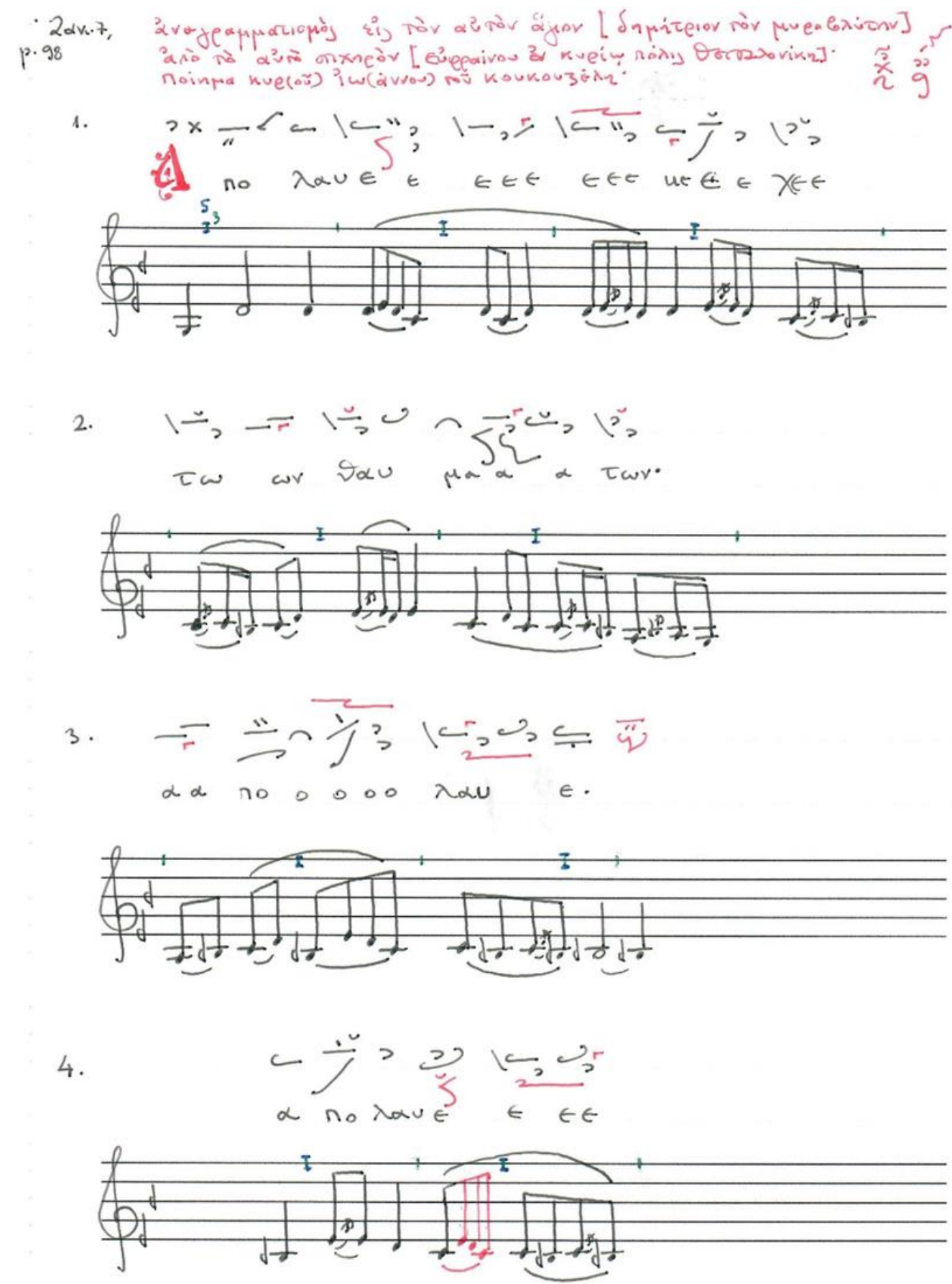

Plate 2. The basic intervallic and rhythmic structure - metrophonia of the mathema Apolaue ton thaumaton, based on research conducted by E. Jammers, J.v. Biezen, I. \& M. Shkolnik, S. Karas and, especially I. Arvanitis. ${ }^{12}$

\footnotetext{
${ }^{12}$ See footnote 10 and Ewald Jammers, Musik in Byzanz, im päpstlichen Rom und im Frankenreich: Der Choral als Musik der Textaussprache, Abhandlungen der Heidelberger Akademie der Wissenschaften, Phil.-hist. Kl. (Heidelberg, 1962), p. 42-72. Jan van Biezen, The Middle Byzantine Kanon Notation of Manuscript H, A Palaeographic Study with a Transcription of the Melodies of 13 Kanons and a Triodion

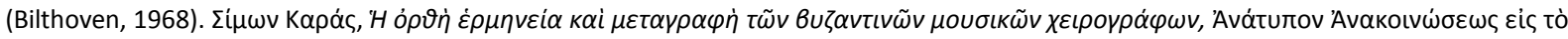

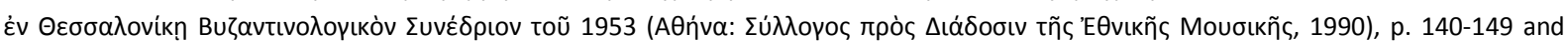
plates 1-9, especially p. 146-148 and plate 4. Marina Shkolnik, "Some Principles of Rhythmic Organization in Byzantine Music (A Study Based on the Byzantine-Russian Heirmologion)," in International Musicological Society, Study Group Cantus Planus, Papers Read at the $7^{\text {th }}$ Meeting, Sopron, Hungary, 1995, edited by László Dobszay (Budapest: Hungarian Academy of Sciences, Institute for Musicology, 1998, p. 537-553. Irina Shkolnik, “Byzantine Prosomoion Singing: A General View on the Repertoire of Stichera-models (automela)," in IMS, Cantus Planus, Papers Read at the $7^{\text {th }}$ Meeting, Sopron, p. 533-536.
} 
In order to explore the phenomenon of the slow exegesis for the kalophonic texture, the entire anagrammatismos Apolaue ton thaumaton has been collated according to the following sources: ${ }^{13}$

- PII: fragment of an Anthologion (contains mainly kalophonic stichera, and therefore this ms has been usually referred to as Sticherarion), A.D. 1400-1450, Library of the Holy Monastery Putna (Romania), $n^{\circ} 56 / 544 / 576$ I, fols. $95 r-96 r{ }^{14}$

- Lm: Anthologion, authograph by the deacon Macarie from the Holy Monastery Dobrovăț, A.D. 1527, today in the library of the Holy Monastery Leimonos, Lesbos (Greece), $n^{\circ} 258$, fols. 269r-271r. ${ }^{15}$

- I: Anthologion, autograph by the Hieromonk Antonie the Precentor, A.D. 1545, kept in Iași, Biblioteca Centrală Universitară "Mihai Eminescu”, n ${ }^{\circ}$ I-26, fols. $137 r-139 v .{ }^{16}$

- Zak. 7 (see details in the introduction), p. 98-99.

- $\quad$ MPT 728 (see details in the introduction), fols. 139v-143v.

Above the neumes from PII and Zak. 7, a microsyntactical analysis is added in violet color, identifying the different kalophonic theseis used in the musical texture of the piece. There is a strong consistence among all the manuscripts with late Middle Byzantine notation. Few variations can be observed, however, among the Putna manuscripts which are almost identical to each other in this piece, and the older, Zakynthian copy, as to the occurence of some great signs, such as lygisma, tromikon a.o. Above the microsyntactical analysis, the use of musical rhetorical devices is shown in green color (palillogia, i.e. sequence, mimesis pros ta nooumena, i.e. word painting a.o.). ${ }^{17}$

Zak. 7 is also accompanied by a staff transnotation, whereas below the neumes of the slow exegesis from MPT 728 a schematic transcription is given. ${ }^{18}$ It shows the melody with its basic rhythm, without containing further ornaments and attractions. These belong to the oral tradition and would display small variations each time the piece is performed by a traditional chanter. Below the transcription, a generative analysis for the exegesis is added in blue color, referring to the following elements:

a. the number of beats per syllable,

b. the melodic contour and the structural notes as revealed in the exegesis (white rhombs show the structural notes, dark ones the edges of the melodic evolvement, oblique lines the stepwise movement of the melody, and the dotted legati show the presence of structural notes at several points of the melodic phrase)

c. the ambitus of the syllable and of the phrase, measured in 'voices' (intervals of second, i.e. 0 stands for a prime, 1 for a second, 2 for a third etc.): see plate 3.

The kolon-numbering is shown at the beginning of each line of the slow exegesis. The first number refers to the kola from Zak 7, whereas the second one in smaller case shows the phrases derivated from each kolon through the slow exegesis.

\footnotetext{
${ }^{13}$ For the description of the first three manuscripts which belong to the Putna Music School, cf. Traian Ocneanu, "The School of Medieval Chant at the Monastery of Putna. Current State of Romanian Research," Școala de la Putna, Acta Musicae Byzantinae VIII (Iași: Centrul de Studii Bizantine, 2005), p. 116-129: 121-125. See also the books mentioned in the following two footnotes.

${ }^{14}$ Cf. Gheorghe Ciobanu, Marin Ionescu, and Titus Moisescu, Școala Muzicală de la Putna. Ms. Nr. 56/544/576 I-P.II - Stihirar, Transcrieri în notație liniară, Izvoare ale Muzicii Românești III B, Transcripta (Bucureşti: Editura Muzicală, 1984).

${ }^{15}$ Titus Moisescu, ed., Manuscrisul de la Dobrovăţ. Ms. 258 / Leimonos, Izvoare ale Muzicii Româneşti XI, Monumenta, Şcoala Muzicală de la Putna (Bucureşti: Editura Muzicală, 1994).

${ }^{16}$ Gheorghe Ciobanu, Marin Ionescu, and Titus Moisescu, eds., Școala Muzicală de la Putna, Manuscrisul nr. I-26 lași. Antologhion din Biblioteca Centrală Universitară "Mihai Eminescu” - Iași, Izvoare ale Muzicii Româneşti IV, Documenta (Bucureşti: Editura Muzicală, 1981).

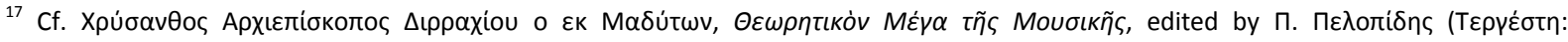

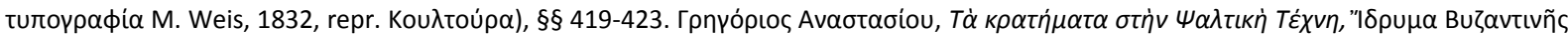

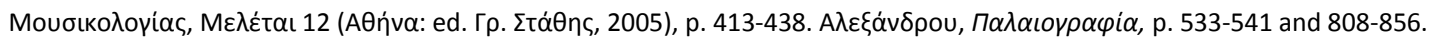

${ }^{18}$ For the alteration signs used in the transcription, cf. ibid., p. 866.
} 


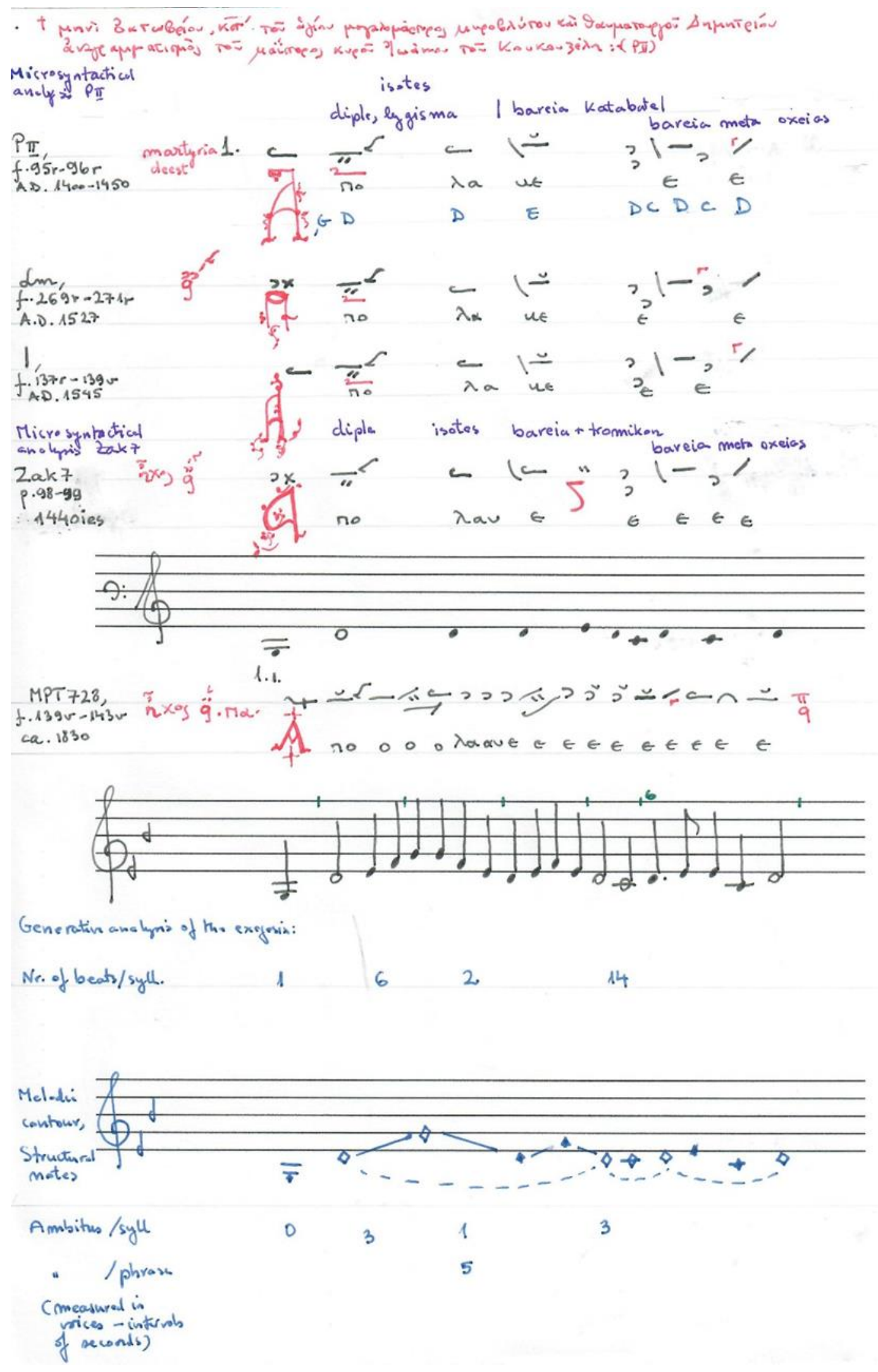

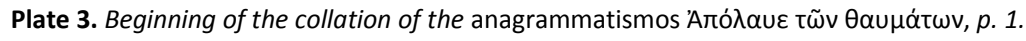


The full collation of the piece led to several observations presented below: ${ }^{19}$

- Periodicity in the exegesis: 2 or 4 beats in the exegesis for each sign of the Middlebyzantine notation (p. $11 \rightarrow$ plate 4, p. 42), or mainly 8 beats per thesis (p. $80 \rightarrow$ plate 22 ).

- Ambitus in the exegesis:

$\checkmark$ per syllable: many times a fourth, but also a prime, second, third, fifth or sixth, depending on the duration of the syllable

$\checkmark$ per phrase: fourth, fifth, sixth, seventh or octave, again depending on the length of the phrase (p. $74 \rightarrow$ plate 21, p. 82-83).

- $\quad$ Exegeses of different formulas (theseis):

$\checkmark$ isotes (p. $10 \rightarrow$ plate 5)

$\checkmark$ anabasis (p. 12-13 $\rightarrow$ plates 7-8, p. 15)

$\checkmark$ tromikon-strepton (p. $30 \rightarrow$ plate 13, p. 42)

- $\quad$ Exegeses of descending sequences:

$\checkmark \quad$ usually different for each melodic cell (p. 23-25 $\rightarrow$ plates 10-12, p. 32, 38-39)

$\checkmark$ sometimes the same for each melodic cell (p. $\mathbf{8 0} \rightarrow$ plate 22 ).

- $\quad$ Almost infinite melodic and rhythmic variations around the structural notes (p. 36-37 $\rightarrow$ plates 14-15).

- The craft of exegesis: the climax zone with different exegeses for the same chain of neumes in the Middlebyzantine notation (p. 50-54 $\rightarrow$ plates 16-20).

- Musical rhetorical devices:

$\checkmark$ many sequences (always descending), with formulas such as: strangismata, bareia+petaste with lygisma, parakletike

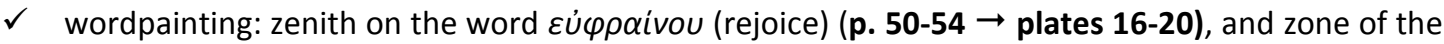
nadir with chromatic phrases on the text $\tau \tilde{\omega} v B \alpha \rho \beta \dot{\alpha} \rho \omega v \tau \dot{\alpha} \vartheta \rho \alpha \dot{\sigma} \sigma$ (rashness of the barbars). This is followed by a kratema which emerges on the syllables tiriri from the last word of the previous text, thrasi (cf. the text of kola 34-37 on table 1).

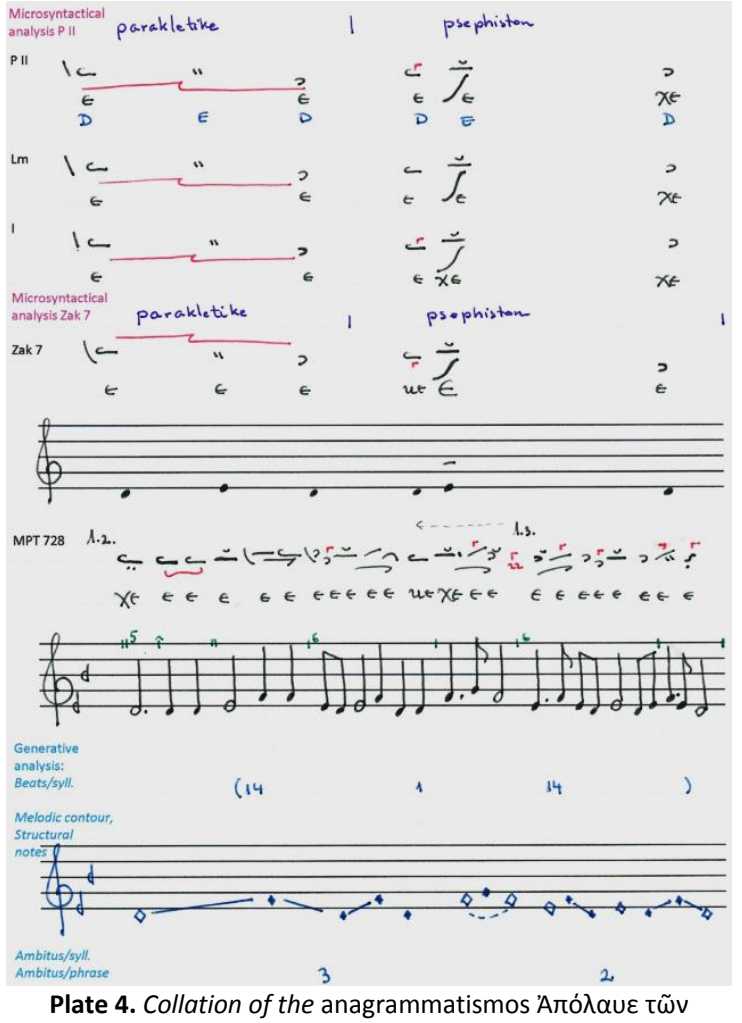
$\theta \alpha u \mu \alpha \dot{\tau} \omega v, p .2$

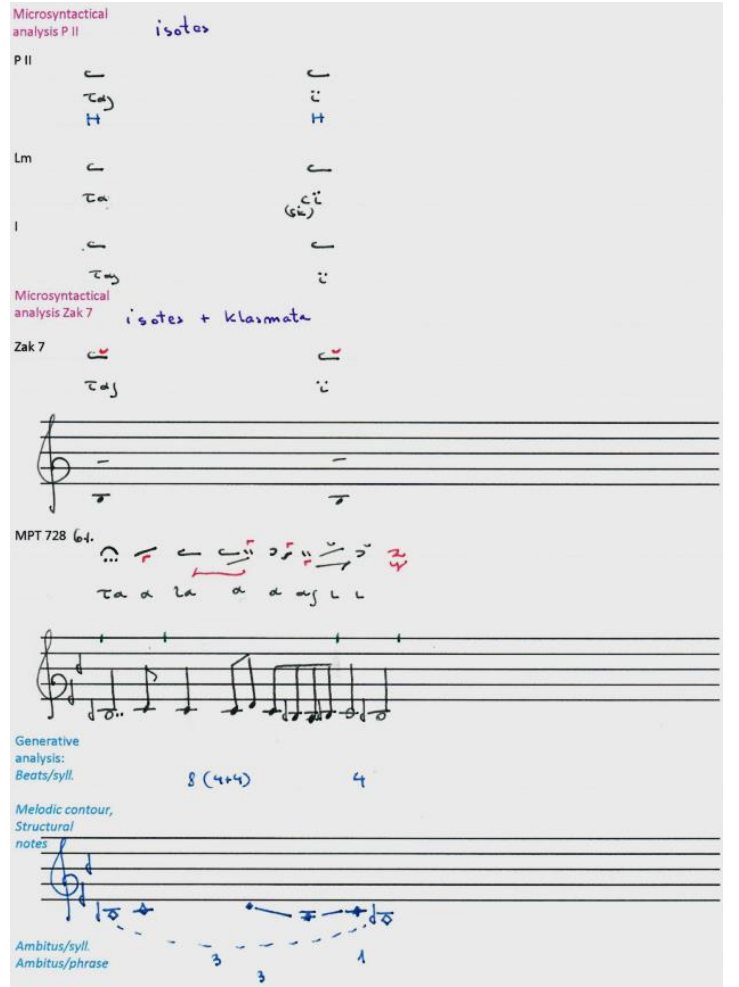

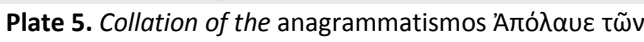

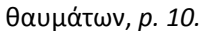

\footnotetext{
${ }^{19}$ In parenthesis, some characteristic examples with the indication of the correspondent page-number of the collation are indicated. Those included in this article are given in bold, along with the correspondent plate-number. Some predominant features of the exegesis are also highlighted in bold characters.
} 


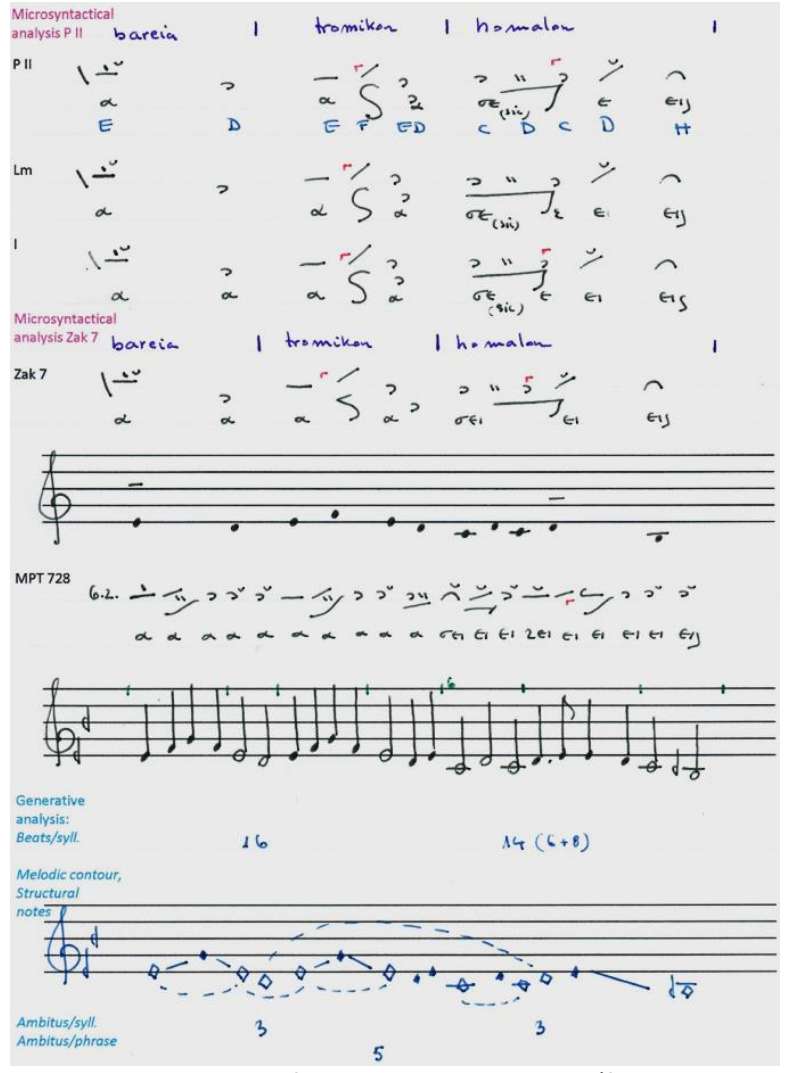

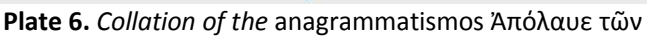
$\theta \alpha u \mu \alpha \dot{\tau} \omega v, p .11$.

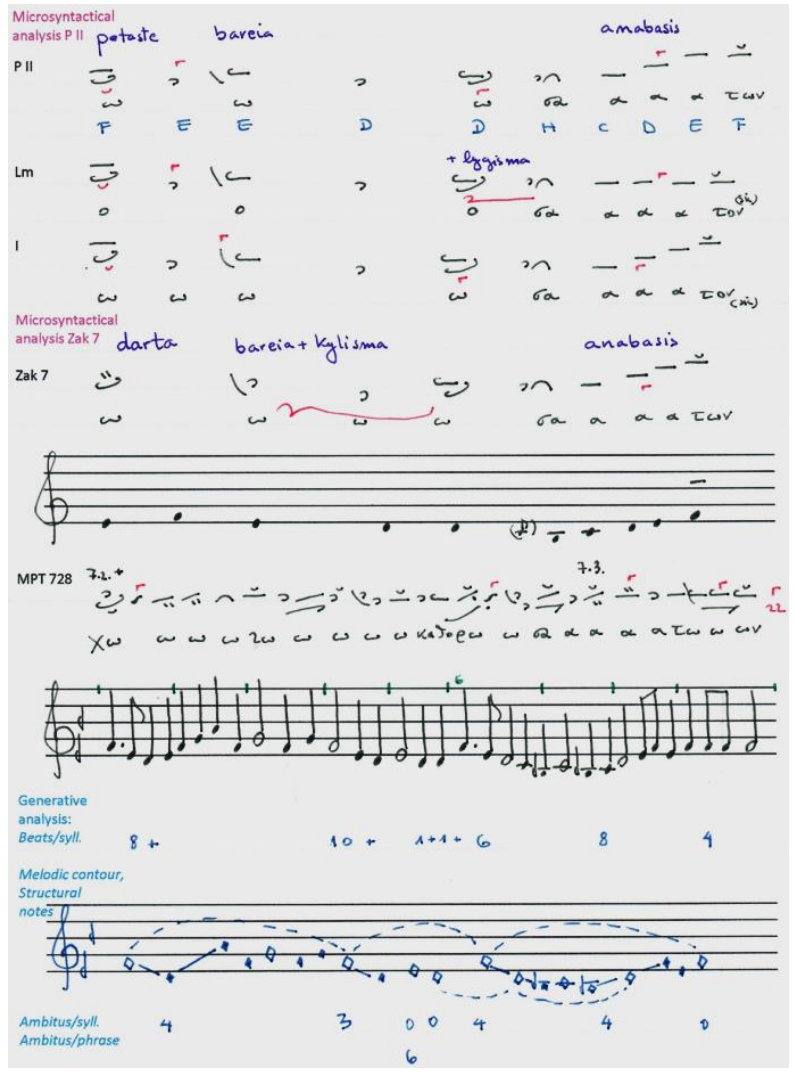

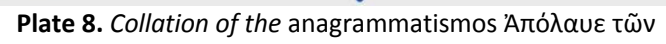

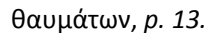

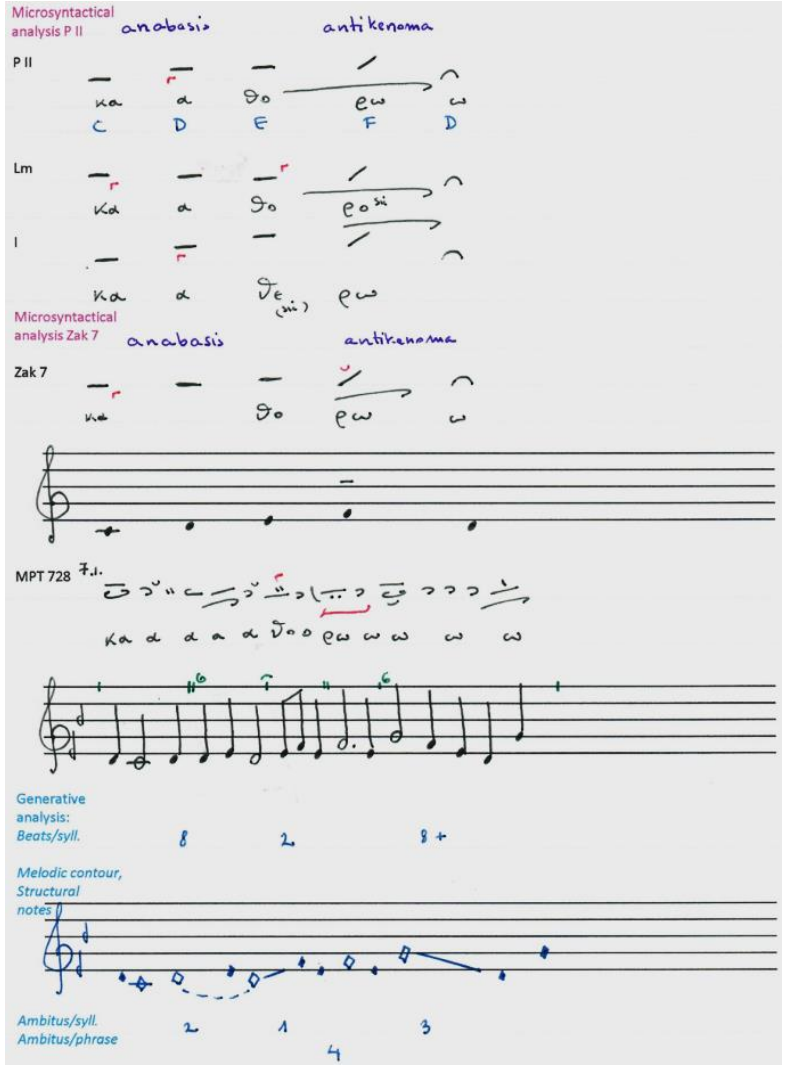

Plate 7. Collation of the anagrammatismos 'Aлó $\lambda \alpha u \varepsilon \tau \tilde{\tau} v$

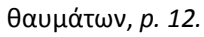

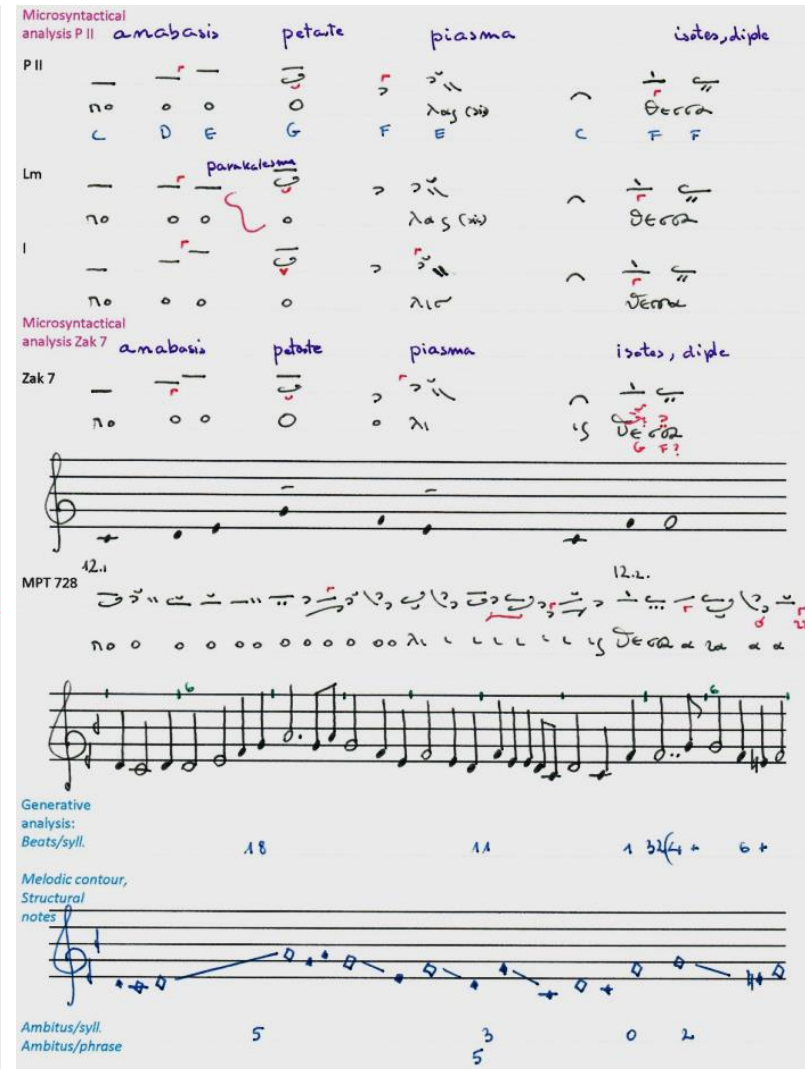

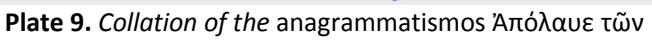

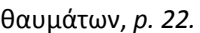




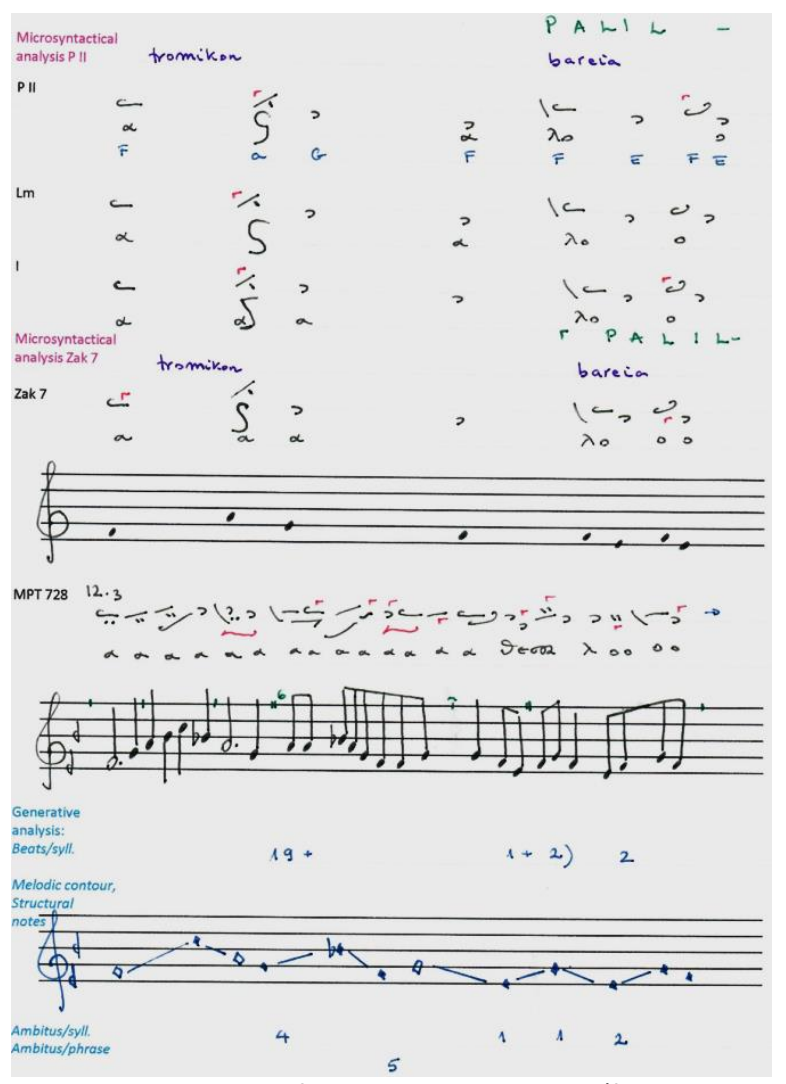

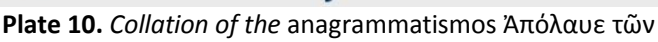

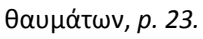

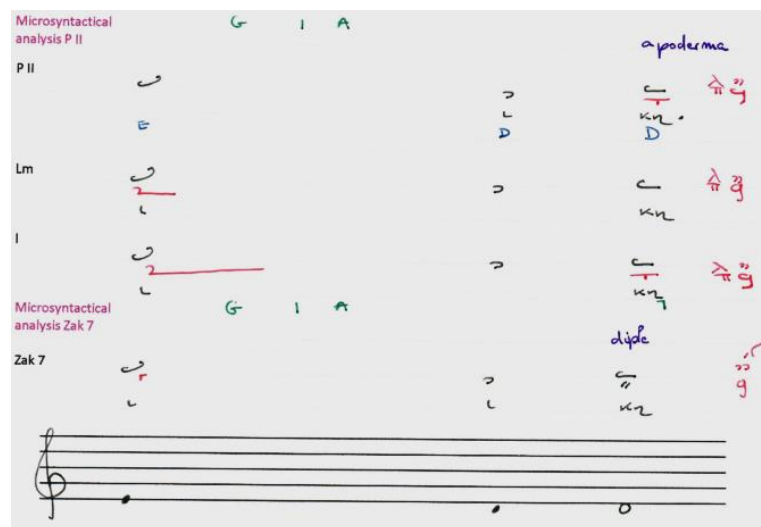

MPт 728 12.5
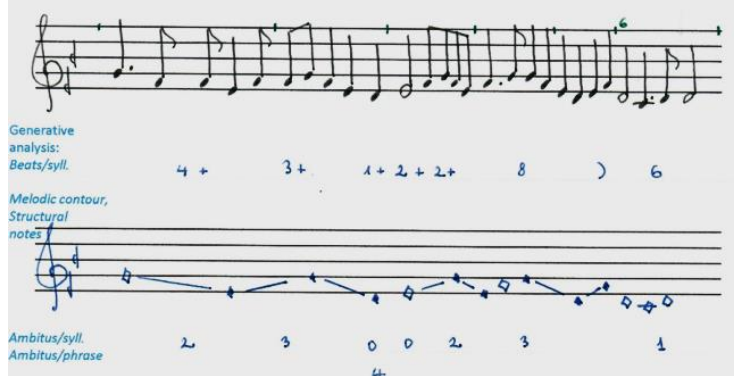

Plate 12. Collation of the anagrammatismos 'Aлó $\lambda \alpha u \varepsilon \tau \tilde{\tau} \mathrm{v}$

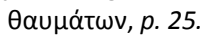

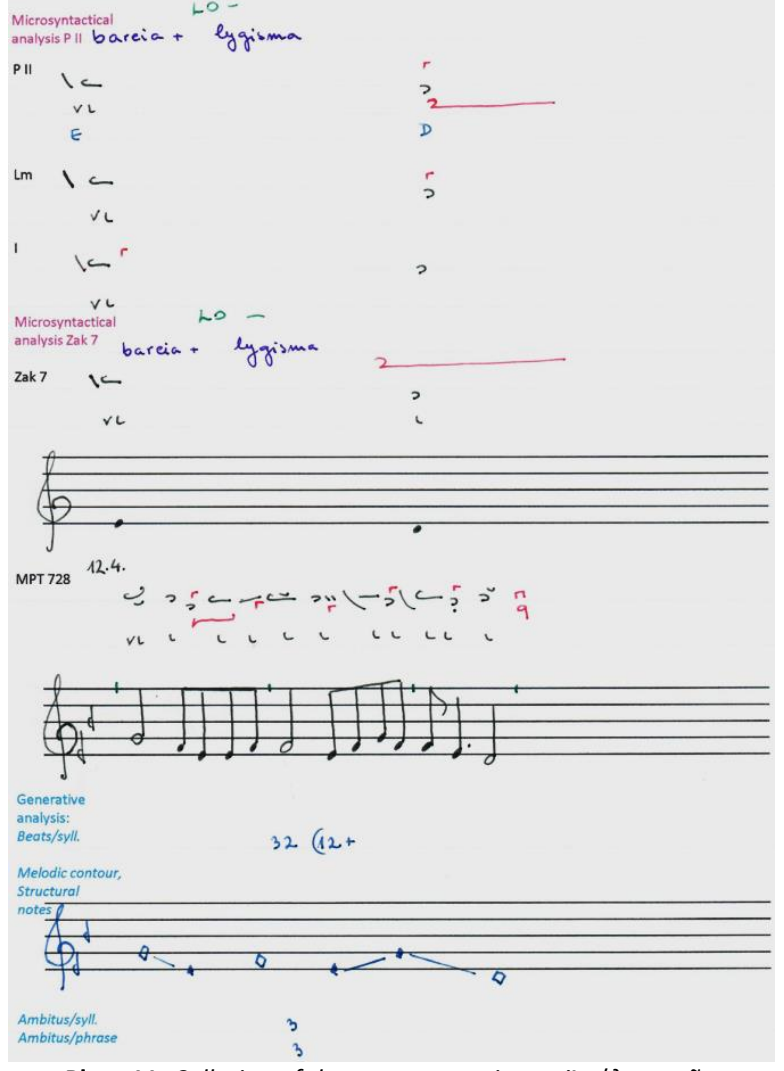

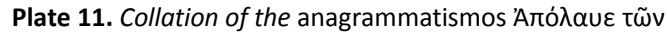

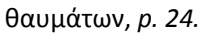
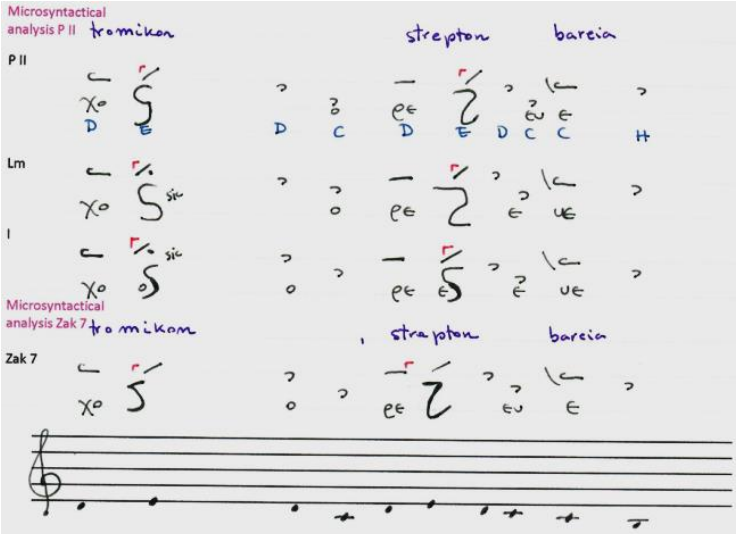

15.

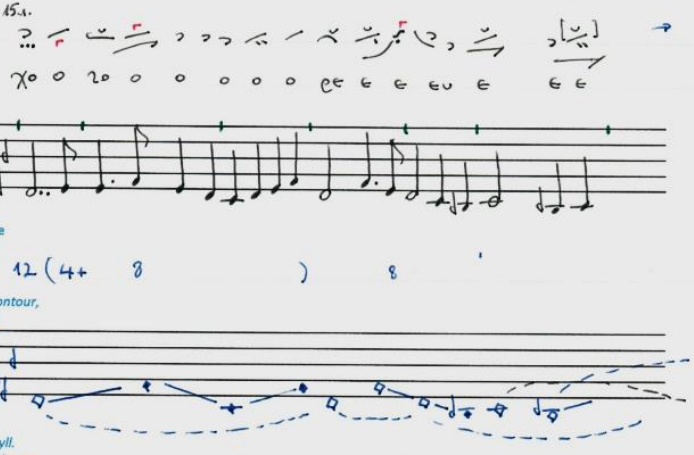

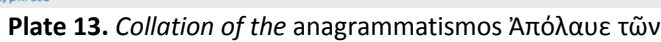

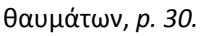




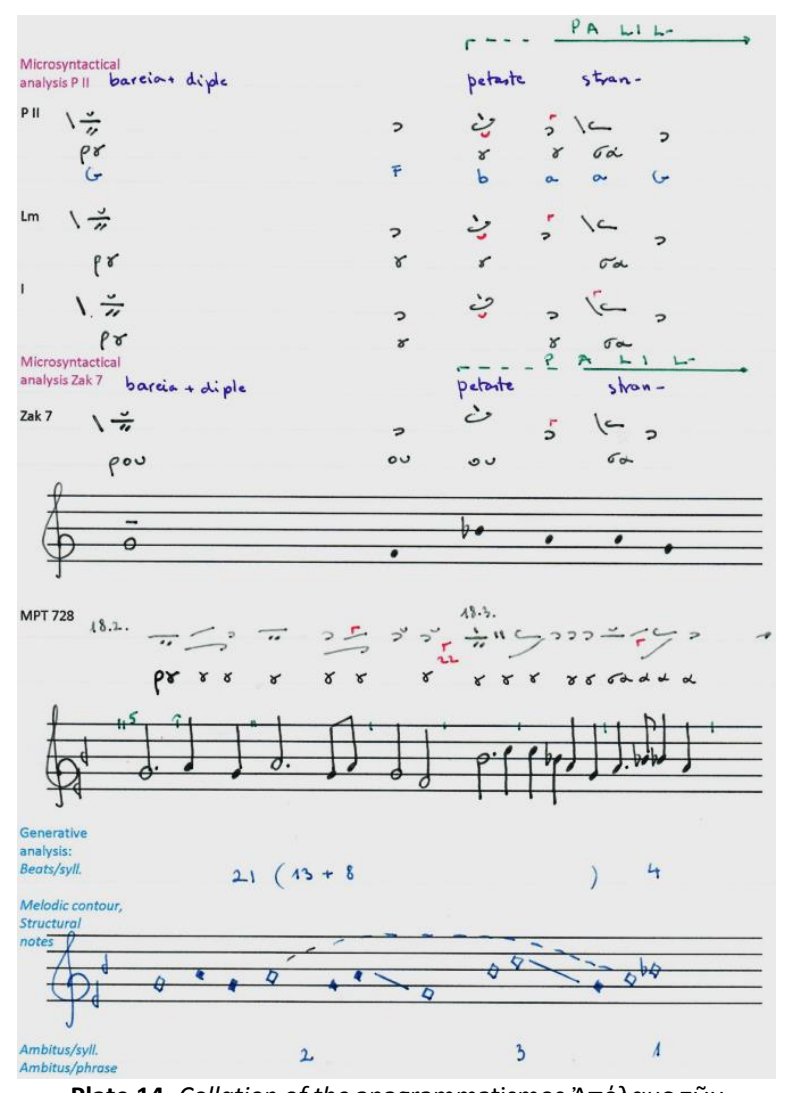

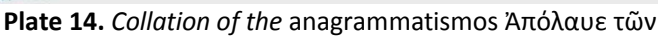

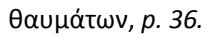

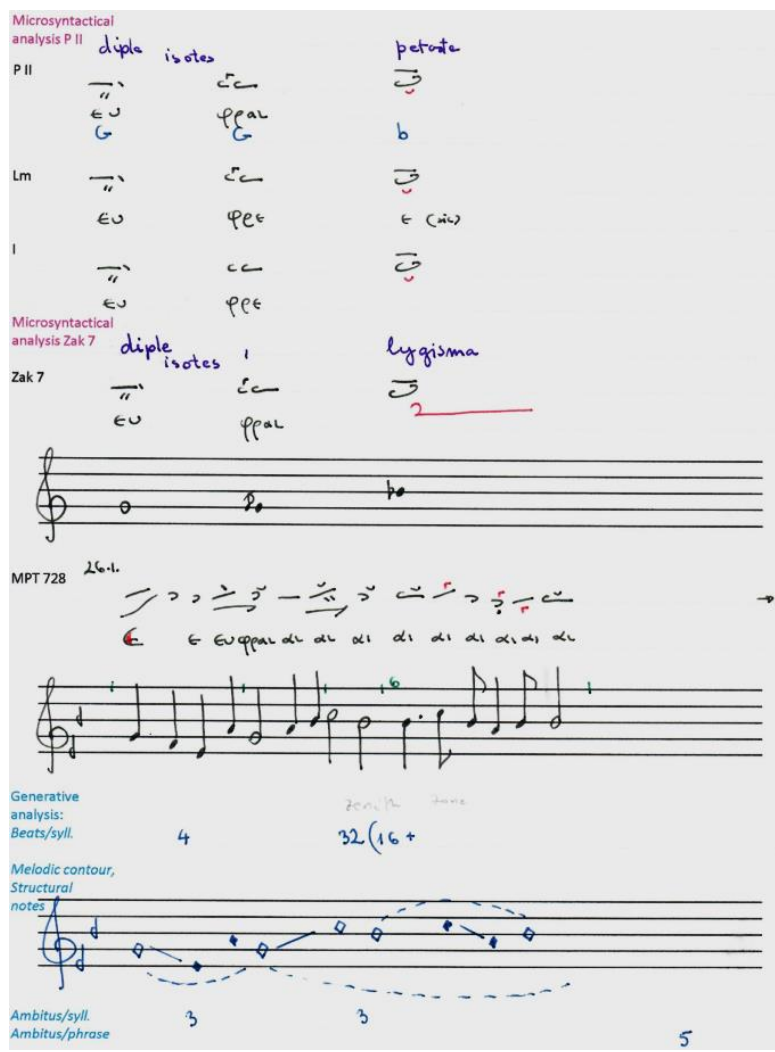

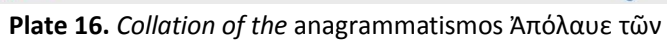

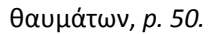

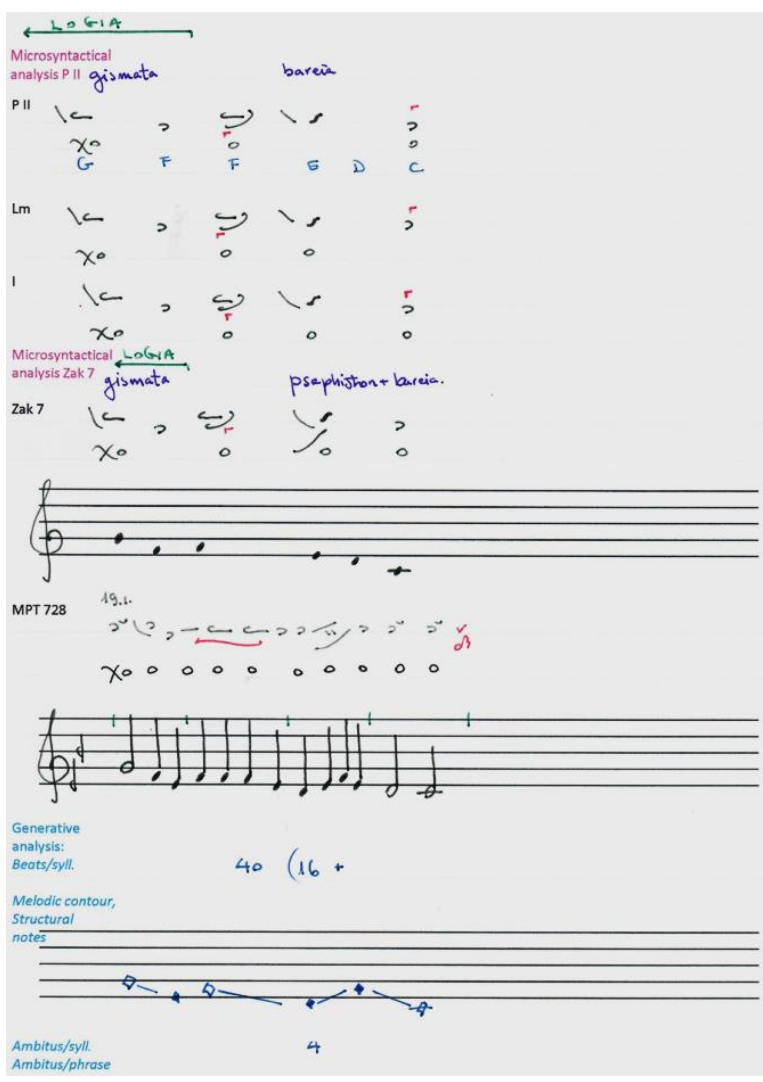

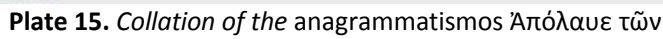

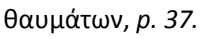

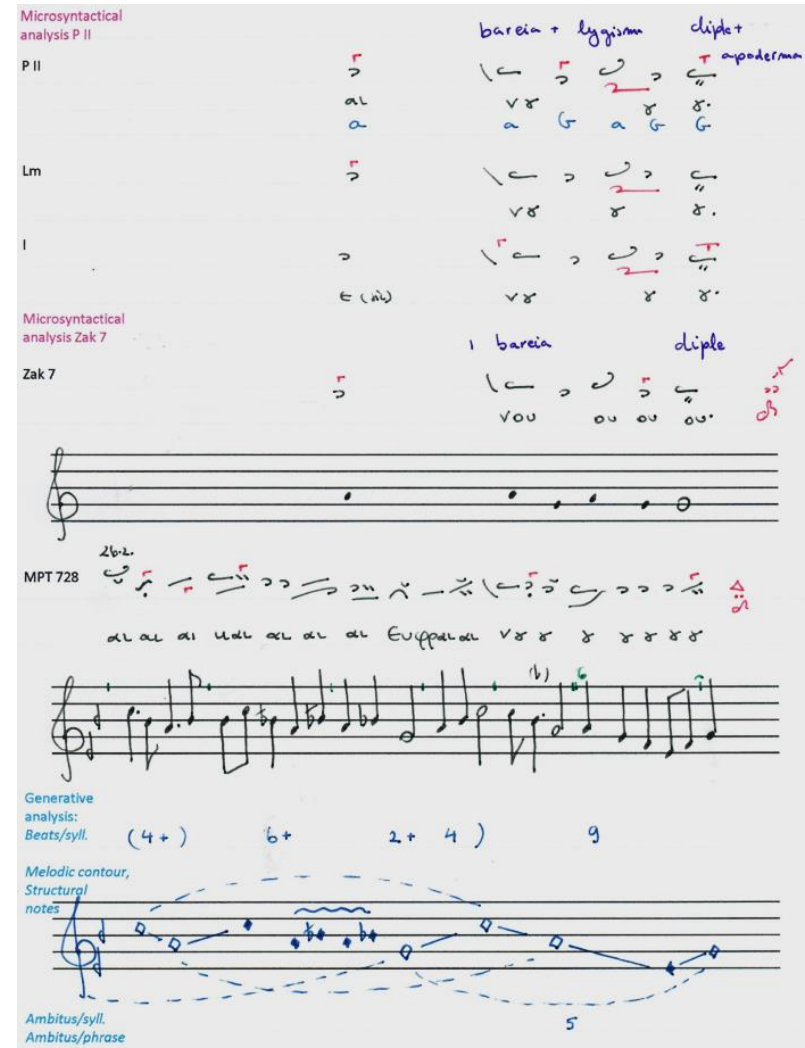

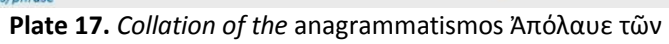
$\theta \alpha u \mu \alpha \dot{\tau} \omega v, p .51$. 


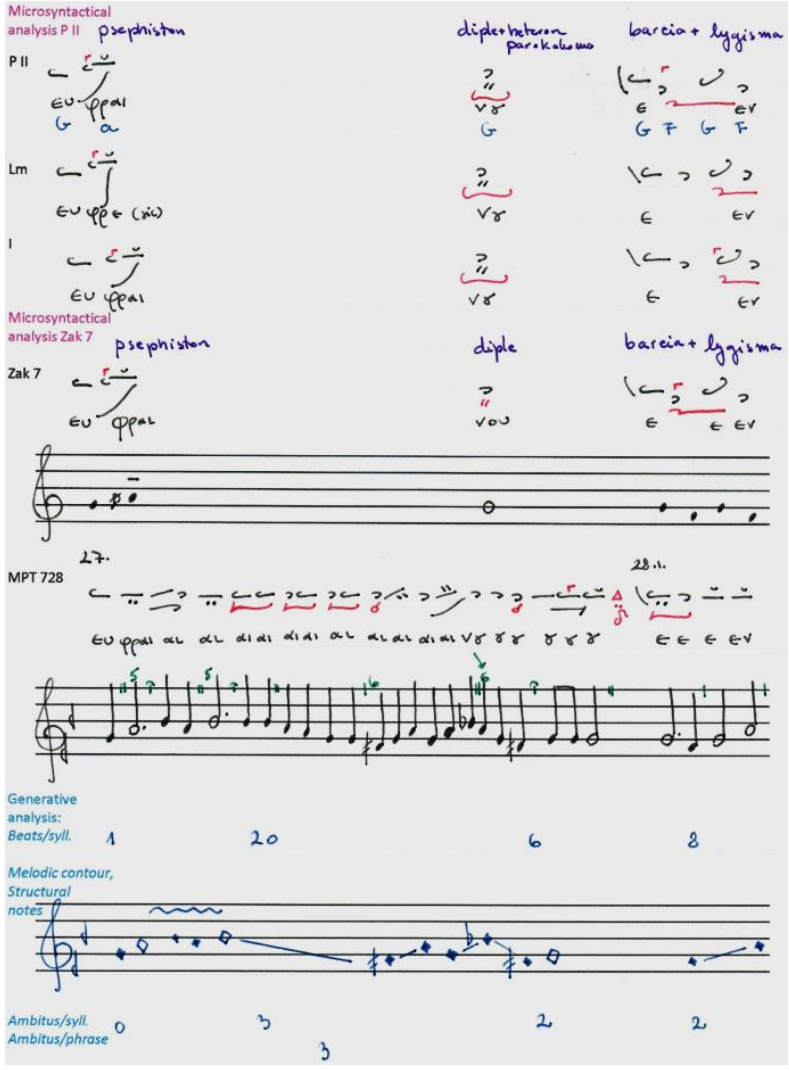

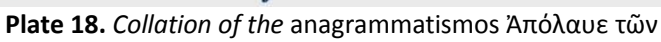

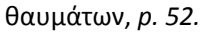

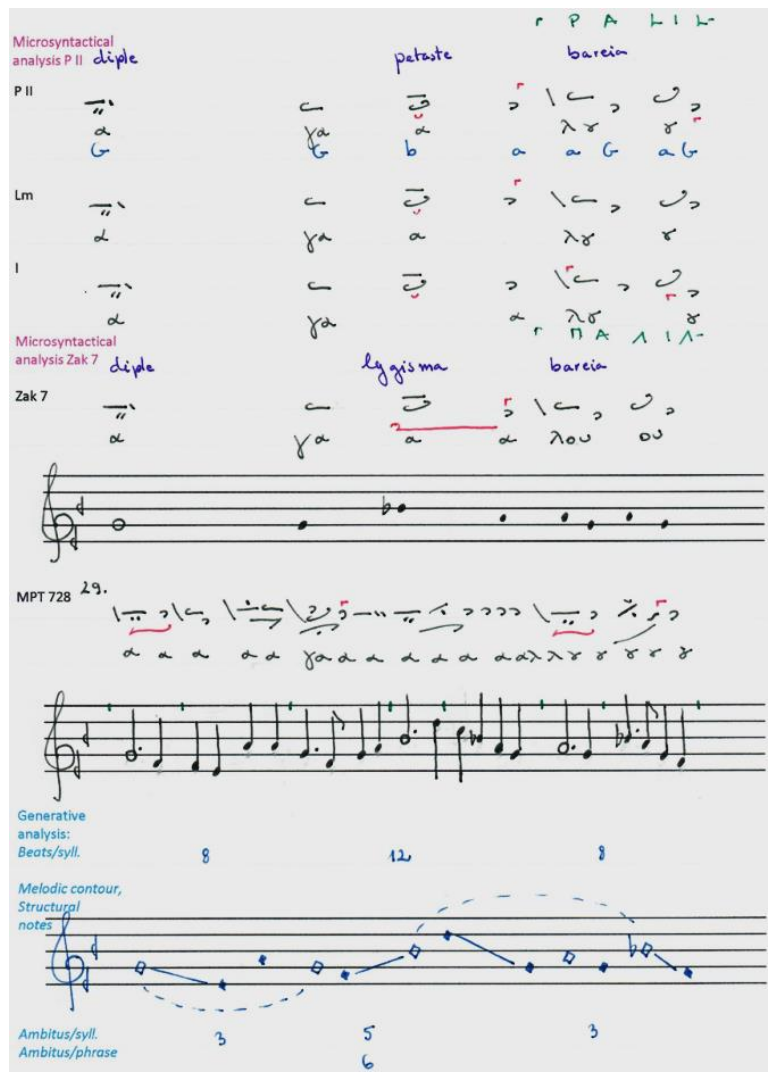

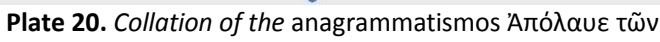
Ө $\alpha u \mu \alpha \dot{\tau} \omega v$, p. 54.

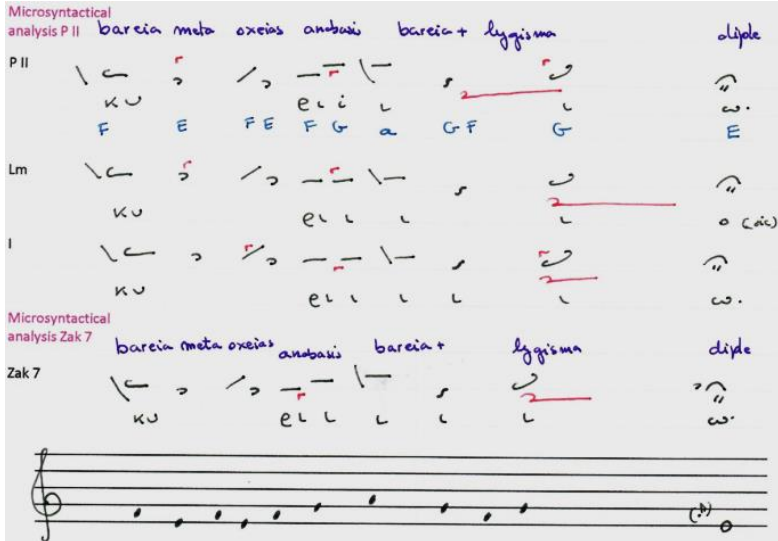

MPT 728 28.2.

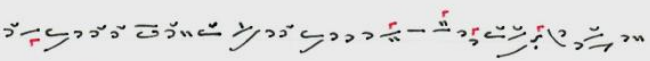

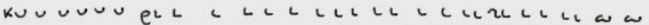
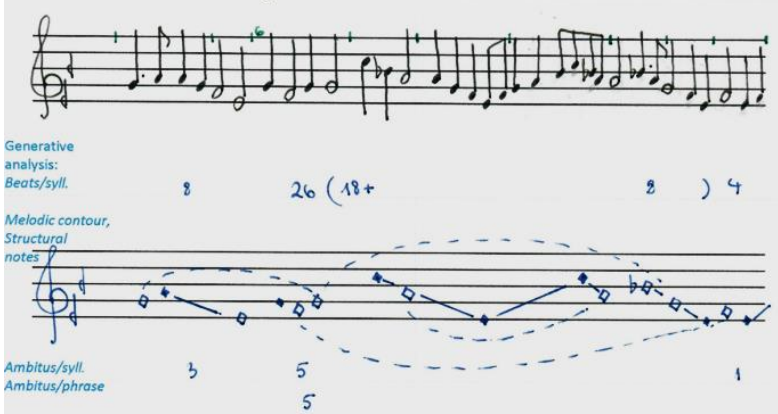

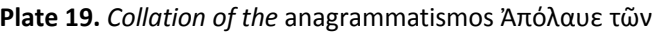

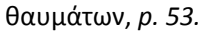

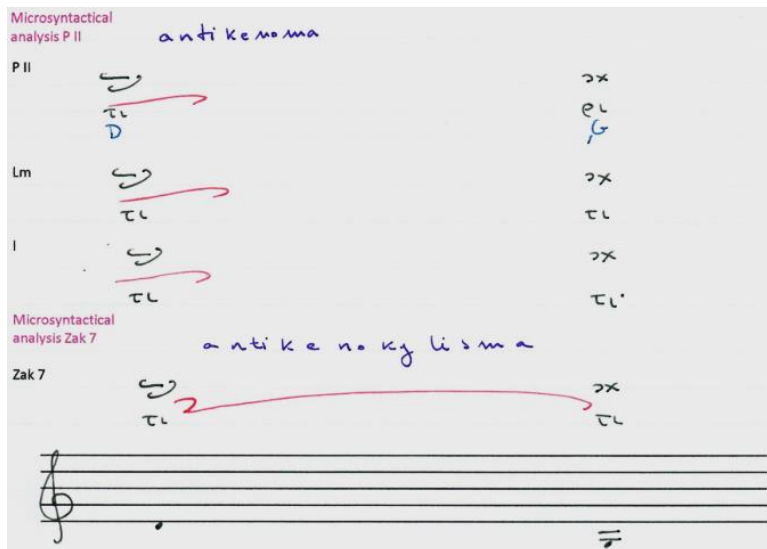

MPT 728 44.

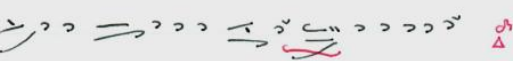

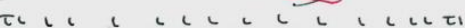

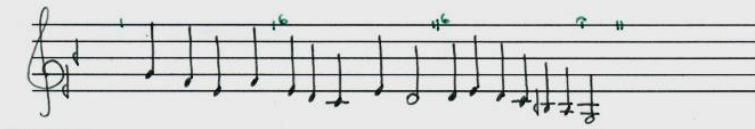

Generative
analysis:
Beytsylt

analysis:
Beouts/syll.

Melodic conto
Structurel
noters

7

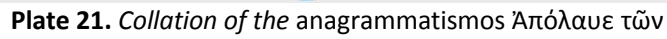
Ө $\alpha u \mu \alpha \dot{\tau} \omega v, p .74$. 


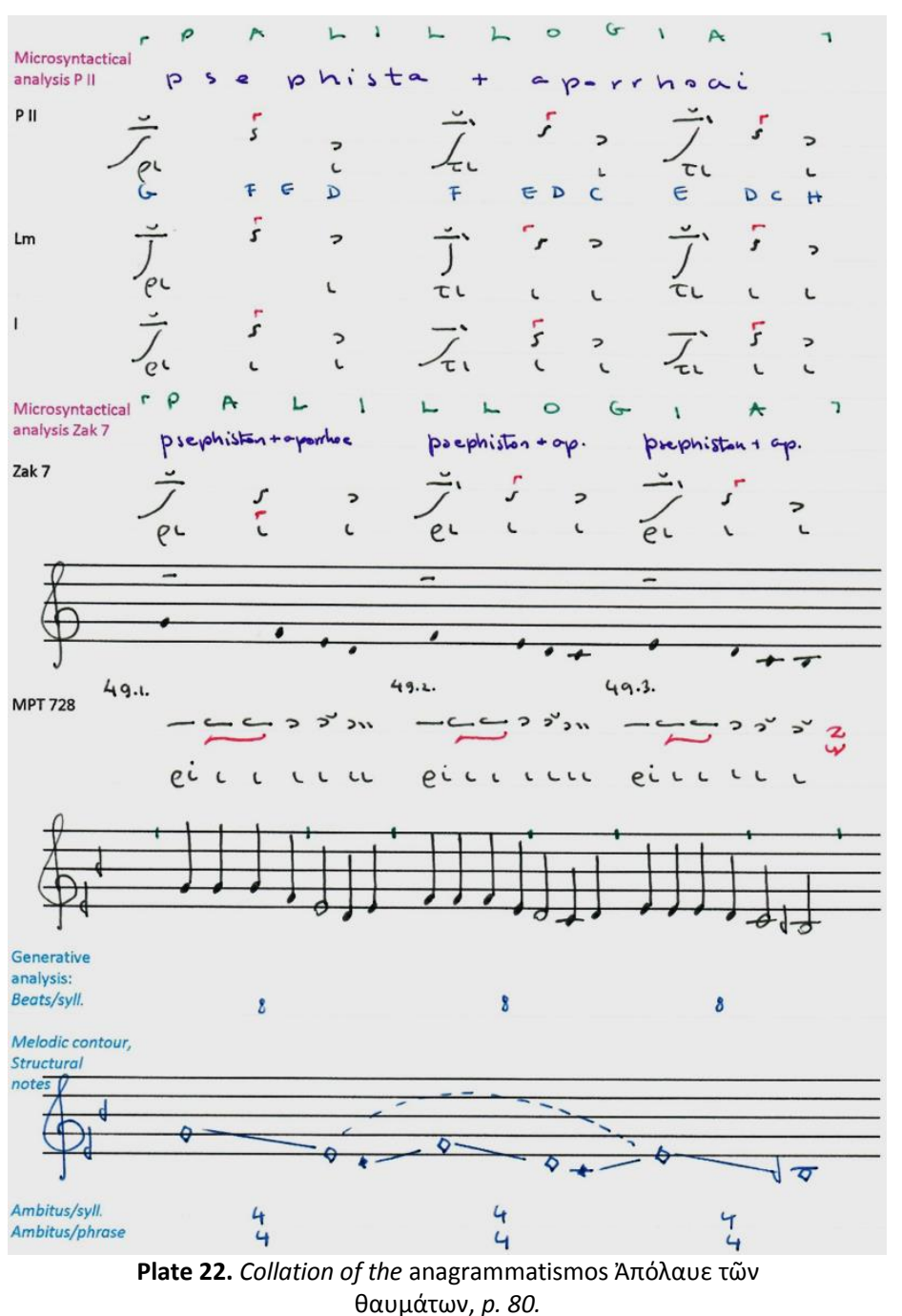

\section{Conclusion}

Below one can find some observations towards a rough description of Byzantine melodics, a sort of sketch of its profile in the kalophonic style, as revealed in the exegesis of the kalophonic style by Chourmouzios Chartophylax. Again we include some examples from the anagrammatismos Apolaue ton iamaton in honor of St Demetrios, in the first mode (with traits of protobarys):

$\checkmark$ The piece can be divided in quaternary meters throughout, with few exceptions only, mainly in the cadential zone, but sometimes also elsewhere in the phrase (see p. $\mathbf{2}$ of the collation $\rightarrow$ plate 4 of this article, and also p. 63, 7879 of the collation).

$\checkmark$ The piece presents an average stepwise movement (ca. $90 \%$ of the entire piece).

$\checkmark$ As to the skips, most of them are ascendent, especially the bigger ones (fourth, fifth a.o.), and are followed by stepwise compensatory descendent movement.

Usually there is one skip per kolon (e.g. p. $11 \rightarrow$ plate 6), but sometimes skips are missing completely (e.g. p. $\mathbf{5 2} \rightarrow$ plate 18). More seldom one encounters two skips in a phrase (e.g. p. $\mathbf{1} \rightarrow$ plate $\mathbf{3}$ ).

$\checkmark$ A hierarchy of notes can be established: 1. structural (melodic pillars), 2. other important notes, 3. melodic passages, broderies, anticipations and delays. The intertwining among them is very subtle and sometimes boudaries are blurred (cf. the generative analysis on the last staff of plates 3-22). ${ }^{20}$

$\checkmark \quad$ The persistance of the structural notes is impressive, and sometimes a sort of 'planing' around them in a smaller or wider melodic ambitus can be observed (p. 50-53 $\rightarrow$ plates 16-19).

$\checkmark$ The kratema displays a different musical texture, with shorter phrases, many repetitions and sequences. The exegesis in the kratema passages is short (p. 74 and $80 \rightarrow$ plates 21 and 22). ${ }^{21}$

Hopefully further research on the mathemata will continue to reveal hitherto hidden aspects and details about the musical texture and modality of the fascinating Byzantine kalophonic repertory and about the oeuvre of great composers such as the 'master of masters' St John Koukouzeles and others, which lifted psaltic art to realms of highest musicianship and prayer.

\footnotetext{
${ }^{20} \mathrm{Cf}$. also loannis Zannos, Ichos und Makam. Vergleichende Untersuchungen zum Tonsystem der griechisch-orthodoxen Kirchenmusik und der türkischen Kunstmusik, Orpheus Schriftenreihe 74 (Bonn: Orpheus-Verlag, 1994), p. 19, 47, 57, 69-70.

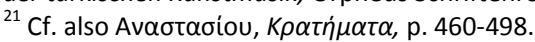




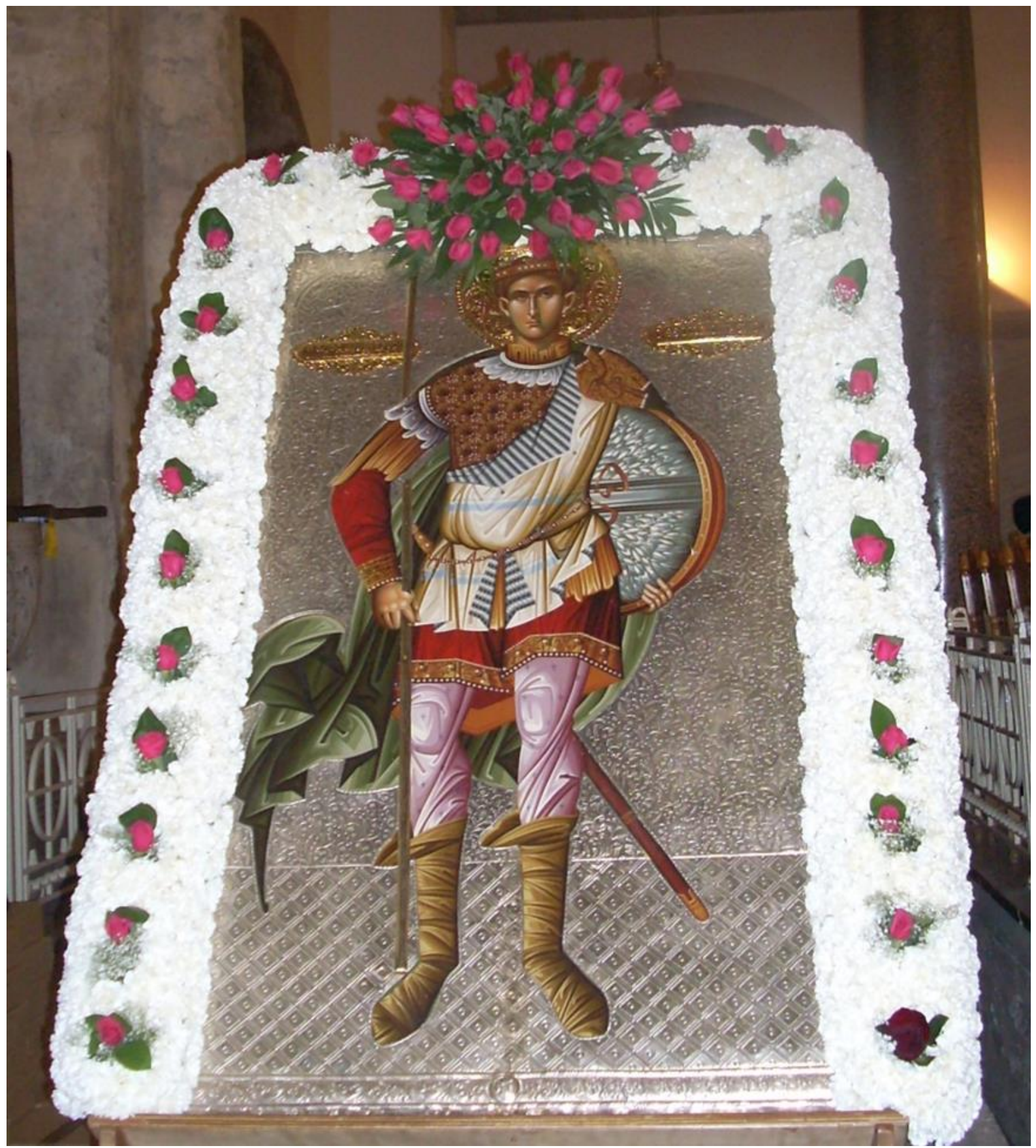

Plate 23. Icon of St Demetrios the Great Martyr and Myroblite, adorned with flowers before the procession through the city of Thessalonica on $25^{\text {th }}$ October (around 2015). ${ }^{22}$

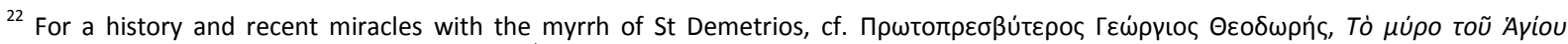

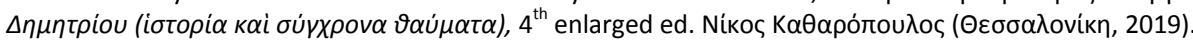




\section{Reference List}

Alexandru, Maria. "Preparations for a Corpus of the Kalophonic Mathemata by St John Koukouzeles" (forthcoming).

"Observations on the diastematic principles in Byzantine musical notations, with emphasis on Gregorios Mpounes Alyates' method of metrophonia, and some links to analogous phenomena in Western Chant." Artes 13 (2013): 129-182.

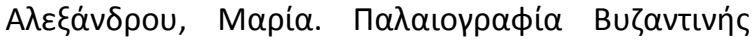

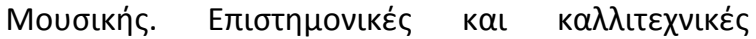

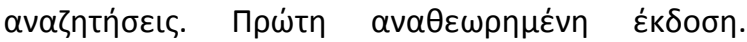

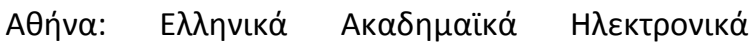

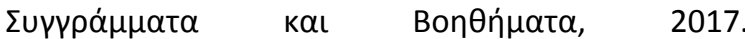
https://repository.kallipos.gr/handle/11419/6487 (opens with mozilla).

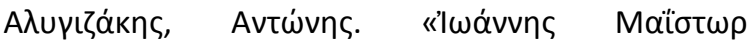

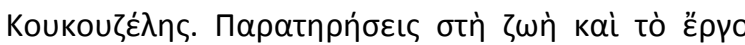

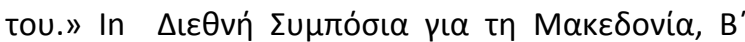

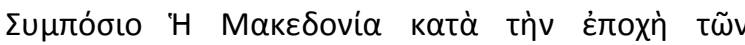

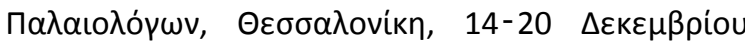

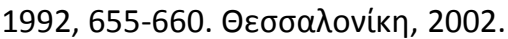

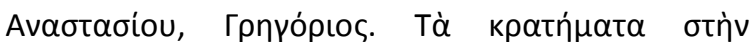

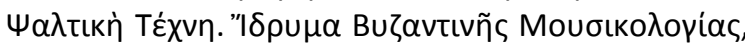

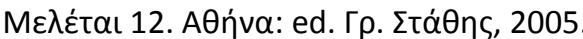

Arvanitis, loannis. "A Way to the Transcription of Old Byzantine Chant by means of Written and Oral Tradition." In Byzantine Chant. Tradition and Reform, Acts of a Meeting held at the Danish Institute at Athens, 1993, edited by Christian Troelsgård, Monographs of the Danish Institute at Athens, vol. II, 123-141. Athens, 1997.

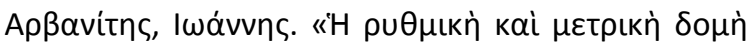

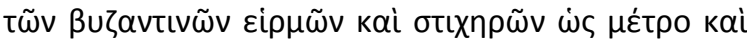

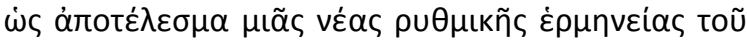

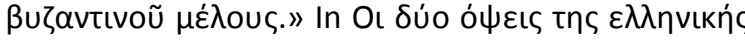

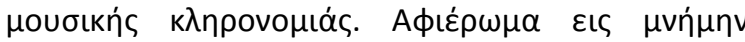

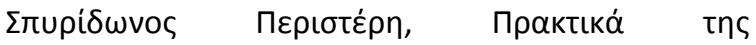

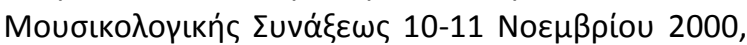

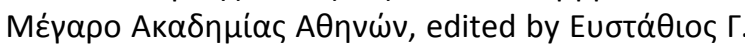

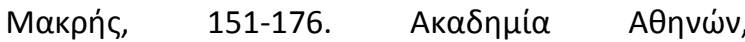

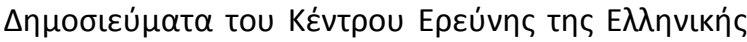

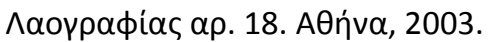

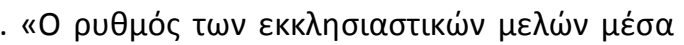

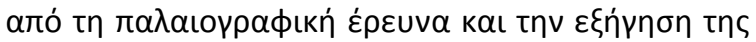

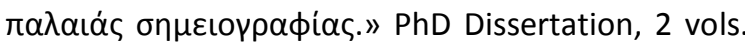

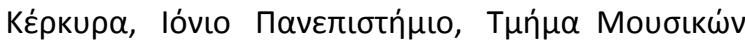

$\Sigma \pi o u \delta \omega \dot{v}$.

Biezen, Jan van. The Middle Byzantine Kanon Notation of Manuscript H. A Palaeographic Study with a Transcription of the Melodies of 13 Kanons and a Triodion. Bilthoven, 1968.

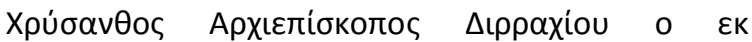

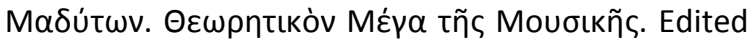

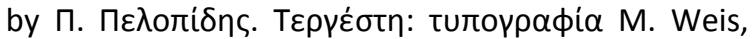

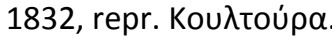

Ciobanu, Gheorghe, and Marin lonescu, eds. Antologhionul lui Evstatie Protopsaltul Putnei. Izvoare ale Muzicii Româneşti V, Documenta. Bucureşti: Editura Muzicală, 1983.

Ciobanu, Gheorghe, Marin Ionescu, and Titus Moisescu. Școala Muzicală de la Putna. Ms. Nr. 56/544/576 I - P.II - Stihirar, Transcrieri în notație liniară. Izvoare ale Muzicii Românești III B, Transcripta. Bucureşti: Editura Muzicală, 1984.

Ciobanu, Gheorghe, Marin Ionescu, and Titus Moisescu, eds. Școala Muzicală de la Putna, Manuscrisul nr. I-26 lași. Antologhion din Biblioteca Centrală Universitară "Mihai Eminescu" - Iași. Izvoare ale Muzicii Româneşti IV, Documenta. Bucureşti: Editura Muzicală, 1981.

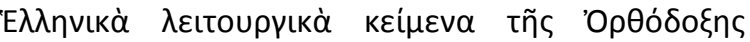

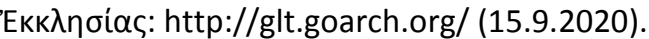

Jammers, Ewald. Musik in Byzanz, im päpstlichen Rom und im Frankenreich: Der Choral als Musik der Textaussprache. Abhandlungen der Heidelberger Akademie der Wissenschaften, Phil.-hist. KI. Heidelberg, 1962.

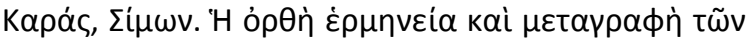

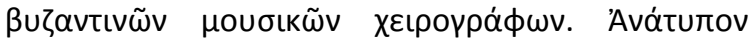

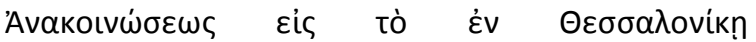

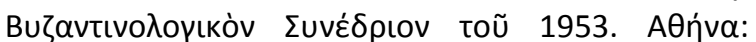

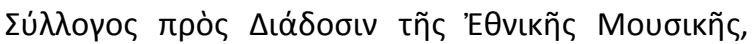
1990.

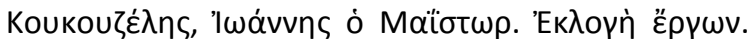

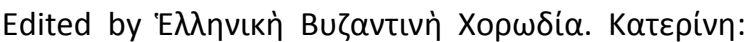

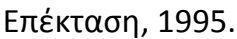

Levy, Kenneth. "Le 'tournant décisif' dans I' histoire de la musique byzantine 1071-1261." In XVe Congrès International d'Études Byzantines, Rapports et Co-Rapports. III. Art et Archéologie, 281-288. Athens, 1976. 
Liddell, Henry George, Robert Scott, Sir Henry Stuart Jones, and Roderick McKenzie. A Greek-English Lexicon. With a Supplement 1968, repr. of 9th edition. Oxford: Clarendon Press, 1990. Lingas, Alexander. "Hesychasm and psalmody." In Mount Athos and Byzantine Monasticism, edited by A. Bryer \& M. Cunningham, 155-168. London: Variorum, 1996.

"Preliminary reflections on studying the liturgical place of Byzantine and Slavonic melismatic chant." In Palaeobyzantine Notations III, Acta of the Congress held at Hernen Castle, The Netherlands, in March 2001, edited by G. Wolfram. Eastern Christian Studies 4 (2004): 147-155.

Moisescu, Titus, ed. Manuscrisul de la Dobrovăţ. Ms. 258 / Leimonos. Izvoare ale Muzicii Româneşti XI, Monumenta, Şcoala Muzicală de la Putna. Bucureşti: Editura Muzicală, 1994.

Ocneanu, Traian. "The School of Medieval Chant at the Monastery of Putna. Current State of Romanian Research." Școala de la Putna, Acta Musicae Byzantinae VIII. Iași: Centrul de Studii Bizantine, 2005: 116-129.

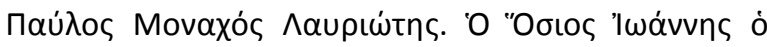

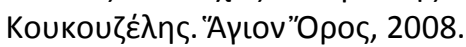

Pennington, Anne E. Muzica în Moldova Medievală. Secolul al XVI-lea, cu un eseu de D. Conomos. Ed. bilingvă (engleză-română) T. Moisescu. Traducere C. Stihi-Boos. Bucureşti: Editura Muzicală, 1985.

Perria, Lidia, and Jørgen Raasted, eds. Sticherarium Ambrosianum. Monumenta Musicae Byzantinae, Facsimiles $\mathrm{XI}$, Pars Principalis. Copenhagen: Munksgaard, 1992.

Shkolnik, Irina. "Byzantine Prosomoion Singing: A General View on the Repertoire of Stichera-models (automela)." In International Musicological Society, Study Group Cantus Planus, Papers Read at the 7th Meeting, Sopron, Hungary, 1995, edited by László Dobszay, 521-536. Budapest: Hungarian Academy of Sciences, Institute for Musicology, 1998.

Shkolnik, Marina. "Some Principles of Rhythmic Organization in Byzantine Music (A Study Based on the Byzantine-Russian Heirmologion)." In International Musicological Society, Study Group Cantus Planus, Papers Read at the 7th Meeting, Sopron, Hungary, 1995, edited by László Dobszay, 537-553. Budapest: Hungarian Academy of Sciences, Institute for Musicology, 1998.

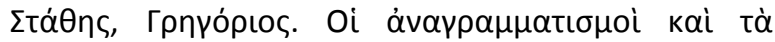

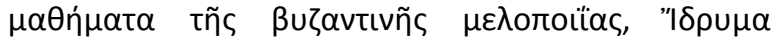

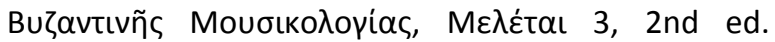
AӨท́va, 1992.

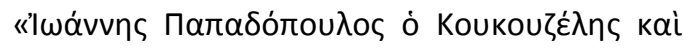

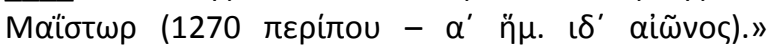

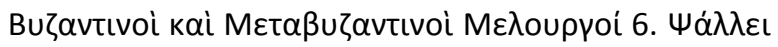

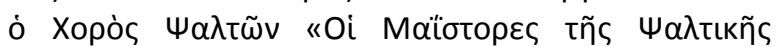

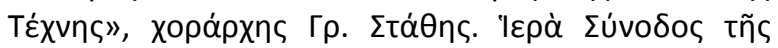

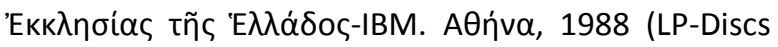
and booklet).

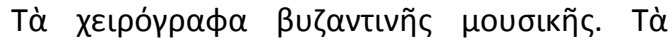

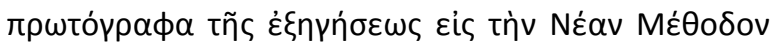

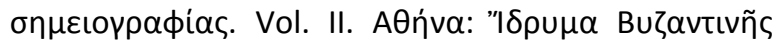
Моuбкколоүi $\alpha$, 2016.

Stathis, Gregorios. "The dekapentasyllabic breaths of the Masters." In Grigorios Stathis, Prinos de mulțumire. Cuvântări la prilejuri festive - Eủxapıotias

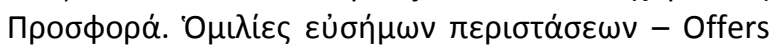
of Gratitude. Speeches on Festive Occasions. Romanian transl. Maria Alexandru, english transl. Sorina Chiper. Edited by Maria Alexandru, Adrian Sîrbu, and Diana-Beatrice Andron, 25-83. Iași: Artes, 2018.

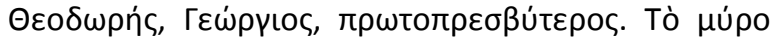

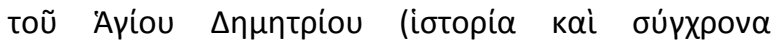

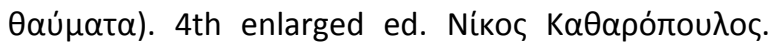

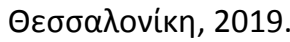

Troelsgård, Christian. "A List of Sticheron CallNumbers of the Standard Abridged Version of the Sticherarion. Part I (The Cycle of the Twelve Months)." Cahiers de I' Institut du Moyen-Âge Grec et Latin $74 \quad$ (2003): 3-20. https://cimagl.saxo.ku.dk/download/74/74Troelsgaar d3-20.pdf (17.9.2020).

Wellesz, Egon. A History of Byzantine Music and Hymnography. 2nd ed. revised and enlarged. Oxford: Clarendon Press, 1962.

Williams, Edward Vinson. “John Koukouzeles' Reform of Byzantine Chanting for Great Vespers in the Fourteenth Century." PhD Dissertation. Yale University, University Microfilms. Ann Arbor, Michigan, 1969.

Zannos, Ioannis. Ichos und Makam. Vergleichende Untersuchungen zum Tonsystem der griechischorthodoxen Kirchenmusik und der türkischen Kunstmusik. Orpheus Schriftenreihe 74. Bonn: Orpheus-Verlag, 1994. 